Hydrol. Earth Syst. Sci., 17, 2029-2051, 2013

www.hydrol-earth-syst-sci.net/17/2029/2013/

doi:10.5194/hess-17-2029-2013

(C) Author(s) 2013. CC Attribution 3.0 License.

\title{
Global multi-scale segmentation of continental and coastal waters from the watersheds to the continental margins
}

\author{
G. G. Laruelle ${ }^{1}$, H. H. Dürr ${ }^{2,4}$, R. Lauerwald ${ }^{1,3}$, J. Hartmann ${ }^{3}$, C. P. Slomp ${ }^{2}$, N. Goossens ${ }^{1}$, and P. A. G. Regnier ${ }^{1}$ \\ ${ }^{1}$ Biogeochemical Modelling of the Earth System, Dept. of Earth \& Environmental Sciences, CP 160/02, \\ Université Libre de Bruxelles, 1050 Brussels, Belgium \\ ${ }^{2}$ Department of Earth Sciences - Geochemistry, Faculty of Geosciences, Utrecht University, Utrecht, the Netherlands \\ ${ }^{3}$ Institute for Biogeochemistry and Marine Chemistry, KlimaCampus, Universität Hamburg, Bundesstrasse 55, \\ 20146 Hamburg, Germany \\ ${ }^{4}$ Ecohydrology Reserach Group, Dept. Earth and Environmental Sciences, University of Waterloo, Waterloo, \\ ON, N2L 3G1, Canada
}

Correspondence to: G. G. Laruelle (goulven.gildas.laruelle@ulb.ac.be)

Received: 20 August 2012 - Published in Hydrol. Earth Syst. Sci. Discuss.: 4 October 2012

Revised: 30 April 2013 - Accepted: 2 May 2013 - Published: 29 May 2013

\begin{abstract}
Past characterizations of the land-ocean continuum were constructed either from a continental perspective through an analysis of watershed river basin properties (COSCATs: COastal Segmentation and related CATchments) or from an oceanic perspective, through a regionalization of the proximal and distal continental margins (LMEs: large marine ecosystems). Here, we present a global-scale coastal segmentation, composed of three consistent levels, that includes the whole aquatic continuum with its riverine, estuarine and shelf sea components. Our work delineates comprehensive ensembles by harmonizing previous segmentations and typologies in order to retain the most important physical characteristics of both the land and shelf areas. The proposed multi-scale segmentation results in a distribution of global exorheic watersheds, estuaries and continental shelf seas among 45 major zones (MARCATS: MARgins and CATchments Segmentation) and 149 sub-units (COSCATs). Geographic and hydrologic parameters such as the surface area, volume and freshwater residence time are calculated for each coastal unit as well as different hypsometric profiles. Our analysis provides detailed insights into the distributions of coastal and continental shelf areas and how they connect with incoming riverine fluxes. The segmentation is also used to re-evaluate the global estuarine $\mathrm{CO}_{2}$ flux at the air-water interface combining global and regional average emission rates derived from local studies.
\end{abstract}

\section{Introduction}

The land-ocean aquatic continuum is commonly defined as the interface, or transition zone, between terrestrial ecosystems and the open ocean (Billen et al., 1991; Mackenzie et al., 2012; Rabouille et al., 2001; Regnier et al., 2013). This continuum includes inland waters, estuaries and coastal waters (Billen et al., 1991; Crossland et al., 2005; Liu et al., 2010), a succession of biogeochemically and physically active systems that not only process large quantities of carbon and nutrients during their natural transit from upland soils to the open ocean (Arndt et al., 2007, 2009; Laruelle, 2009; Mackenzie et al., 2005; Nixon et al., 1996; Regnier and Steefel, 1999; Vanderborght et al., 2002, 2007), but also exchange vertically significant amounts of greenhouse gases with the atmosphere (Cole et al., 2007; Laruelle et al., 2010; Tranvik et al., 2009; Regnier et al., 2013). Although the landocean aquatic continuum is acknowledged to play a significant role in global biogeochemical cycles (Gattuso et al., 1998; Mackenzie et al., 1998; Mantoura et al., 1991), the quantitative contribution of inland waters, estuaries and continental shelves to carbon and nutrient budgets remains entailed with large uncertainties, reflecting primarily the limited availability of field data and the lack of robust upscaling approaches (Regnier et al., 2013).

Over the past few years, a growing number of environmental databases dedicated to inland waters (GLORICH, 
Hartmann et al., 2011), estuaries (Engle et al., 2007) and the coastal zone have been assembled (LOICZ, Crossland et al., 2005). Extrapolation of the numerous local measurements in these databases to provide regional and global budgets calls for the segmentation of the aquatic continuum into areas of broadly similar biogeochemical and physical behaviour, based on multiple criteria such as climate, morphology and physical forcings. In addition, the surface area and volume of the resulting segments need to be constrained for budgeting purposes, a task that is more complex than one might actually presume. For instance, the geographical extent of the continental shelf itself (i.e. the extended perimeter of a continent, usually covered by shallow seas) is still a matter of debate (Borges et al., 2005; Chen et al., 2012; Liu et al., 2010), partly because there is no common definition of its outer limit. So far, the delineation of the coastal ocean has been constrained using administrative limits (Sherman and Alexander, 1989), the $200 \mathrm{~m}$ isobaths (Walsh, 1988) or the maximum increase in slope of the seabed (Liu et al., 2010), leading to surface area estimates that differ by up to $20 \%$. Similar issues arise for the delineation of regional boundaries on land (Meybeck et al., 2006, 2013). It has however been shown that a careful segmentation of continental shelf seas into representative units together with a robust, GIS-based estimation of the corresponding surface areas contributes to improved biogeochemical budgets, as exemplified by the revised global air-water $\mathrm{CO}_{2}$ exchange flux estimated by Laruelle et al. (2010) for the coastal ocean.

At the global scale, a segmentation that incorporates consistently the aquatic continuum of inland waters, estuaries and continental shelves remains to be developed. A major difficulty arises because their spatial scales are fundamentally different and may vary regionally. For instance, estuaries exhibit typical length and width scales ranging from 1 to $100 \mathrm{~km}$ and are thus much smaller entities than large-scale coastal entities delimited by well-established currents such as the Gulf Stream or the California Current, which flow along continents over thousands of kilometres (Longhurst, 1998). The largest rivers in the world exceed thousands of kilometres in length but require a representation of their river network at resolutions $<1$ degree for a proper identification of the routing of their main tributaries (Vörösmarty et al., 2000a, b). Moreover, environmental databases gathering monitoring data, climatological forcings and average earth surface properties are available under various forms and at different spatial resolutions. Some consist of gridded maps, files or model outputs at 0.5 or 1 degree resolution (World Ocean Atlas, DaSilva et al., 1994; Levitus et al., 1998; GlobalNEWS, Mayorga et al., 2010; Seitzinger et al., 2005) while others are databases containing measurements from millions (SOCAT, Pfeil et al., 2012) to thousands (GLORICH) or just several dozen (Lønborg and Álvarez-Salgado, 2012; Laruelle et al., 2010; Seiter et al., 2005) of unevenly distributed sampling points. Thus, for environmental budgeting purposes, a multi-scale approach is required to integrate and combine this variety of databases.

In this study, we present a harmonized multi-scale segmentation for the land-ocean continuum, from the watershed to the outer limit of the continental shelf. It is based on three increasing levels of aggregation, and the inter-compatibility of these levels not only allows the integration of a wide variety of databases compiled at various spatial resolutions, but also the comparison and combination of them with one another. The first level, at the finer resolution of 0.5 degrees, is based on the work of Vörösmarty et al. (2000a, b) and resolves the watersheds and river routing. It also attributes an estuarine type to each watershed following the typology of Dürr et al. (2011), which includes small deltas, tidal systems, lagoons and fjords. This spatial resolution allows for a realistic representation of the global river network and is compatible with many global databases (World Ocean Atlas, LOICZ, Buddemeier et al., 2008; Crossland et al., 2005). This level is also suitable for detailed regional analyses of coastal regions and their corresponding watersheds. The second level is built on an updated version of the COSCAT (COastal Segmentation and related CATchments) segmentation (Meybeck et al., 2006), which distinguishes different segments of the global coastline based on a combination of terrestrial watershed characteristics and coastal geomorphologic features. It is extended here to include the relevant portions of the adjacent continental shelves. The highest level in the hierarchy is termed MARCATS (for MARgins and CATchments Segmentation) and consists of aggregated COSCAT units according to the main climatological, morphological and oceanographic characteristics of the coastal zone. This new segmentation is inspired by a classification of the continental shelf seas proposed in the recent synthesis by Liu et al. (2010) and defines 45 regional units, which allow for coarser regional analysis and upscaling calculations when data sets are limited. It nevertheless retains the major physical features of many different coastal regions and identifies a number of widely studied systems such as the main regional seas and some major coastal currents. It can be viewed as an analogue to the coarse segmentation of Takahashi et al. (2009) for the estimation of $\mathrm{CO}_{2}$ fluxes in the open ocean.

The novelty of our approach thus lies in the development of an integrated scheme that includes the entire land-ocean continuum. Numerous studies already proposed global segmentations or classifications from either an oceanic (Sherman and Alexander, 1989; Seiter et al., 2005) or terrestrial perspective (Köppen, 1936; Meybeck et al., 2006, 2013; Peel et al., 2007). Here, the COSCAT and MARCATS segmentations were used to calculate, for different isobaths, the surface area and volume of each segment of the coastal ocean as well as the surface areas of watersheds and estuaries. Our estimates are compiled into a global data set that provides a new regionalized assessment of the size of the different compartments of the land-ocean continuum (see also www.biogeomod.net/geomap). The three levels of our 
segmentation can be used in conjunction with biogeochemical databases (e.g. World Ocean Atlas, LOICZ, Hexacoral, GLORICH, SOCAT, and so forth) to establish regional budgets and, eventually, refine global assessments of the carbon and nutrient cycles. This is performed in this study by providing regionalized estimates of $\mathrm{CO}_{2}$ fluxes from estuarine systems at the global scale. Furthermore, the combination of several layers of increasing spatial resolution allows the integration, combination and comparison of various databases through, for example, the calculation of average properties for any given segment (watershed, COSCAT or MARCATS) depending on the data density and availability. The segmentation is also combined with watershed models (e.g. GlobalNEWS) to constrain, for each region of the world, the amount of fresh water that is routed through the different estuarine types and delivered to a given segment of the coastal ocean. These volumes of fresh water are compared to those of the continental shelves they flow into. Although not performed here, the same approach could easily be expanded to terrestrial carbon and nutrient fluxes. Thus, the newly compiled and homogenized data set is applicable in a wide range of future investigations of biogeochemical fluxes along the landocean continuum, which are still largely misrepresented or ignored in current global circulation and Earth system models (Regnier et al., 2013). The GIS files provided in the Supplement will allow the community to alter the approach or to refine local settings if needed.

\section{Segmentation: limits and definitions}

The present study describes a segmentation of continental waters based on three levels of increasing aggregation. The finest segmentation corresponding to the lowest level of aggregation (level I) resolves the 0.5 degree river network of Vörösmarty et al. (2000a, b). This river network is generated using digital elevation models to calculate the direction of the surface water flow in each terrestrial cell of 0.5 degree resolution. The interconnections of the surface water flow direction determine the path of each river and its tributaries. Each watershed is then delineated by the aggregation of all the cells belonging to a given river, and subsequently connected to a coastal cell. The global river network used here includes all inland waters and provides a canvas for a coarser aggregation consisting of a group of riverine watersheds on the continental side and an ensemble of contiguous continental shelf segments on the oceanic side (Fig. 1). This intermediate level of aggregation is based on an updated version of the COSCAT segmentation developed by Meybeck et al. (2006) (level II). Finally, the merging of COSCATs units into larger entities called MARCATS provides the coarsest segmentation (level III).

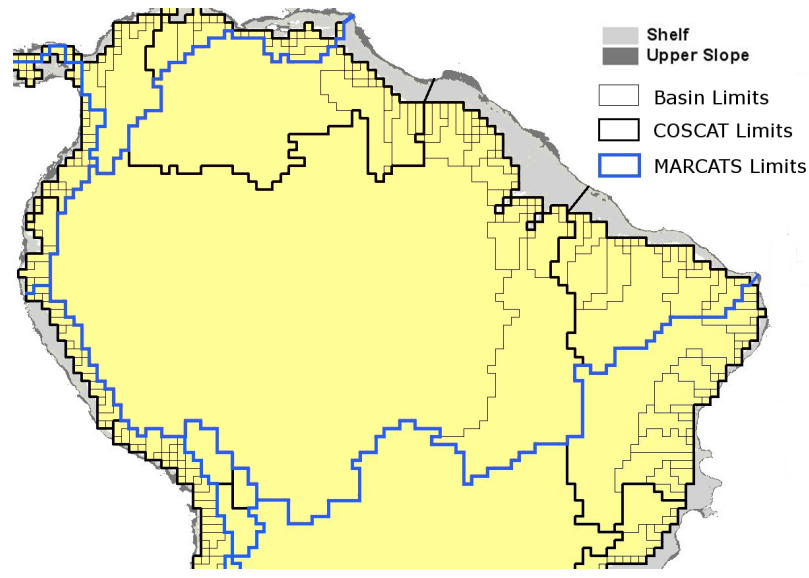

Fig. 1. Map of equatorial South America displaying the 3 layers of the segmentation and their boundaries (1 - watersheds, 2 COSCATs, 3 - MARCATS)

\subsection{COSCAT segmentation and GIS calculations}

The COSCATs are homogeneous geographical units which are independent of administrative borders. They primarily rely on lithological, morphological, climatic and hydrological parameters to partition the global coastline into segments with similar properties. The total number of COSCAT units amounts to 149 for an average coastline length of $3000 \mathrm{~km}$. Meta-watersheds attributed to each coastal segment are constituted of all the individual watersheds whose rivers discharge within the corresponding COSCAT. Following Laruelle et al. (2010), each COSCAT is also associated with a section of the continental shelf adjacent to the coastline. The lateral boundaries of a specific shelf unit are defined by perpendicularly extrapolating the limits of the corresponding coastal segment from the shoreline to the $1000 \mathrm{~m}$ isobaths, extracted from $1 \mathrm{~min}$ resolution global bathymetries (see below). Where the limit between two COSCATs on the shelf corresponds to a major topographic feature such as a submarine ridge or the connection between two oceanic basins, this feature is used as boundary instead. For the purpose of the study, a number of minor modifications were applied to the original COSCAT boundaries, to account for stretches of coasts with similar estuarine characteristics (Dürr et al., 2011) or the profile of some continental shelves. The COSCAT 401 running from the Strait of Gibraltar to the Atlantic border between France and Spain was split into two segments (COSCATs 401 and 419), corresponding to the northern and western Iberian coasts, respectively. The COSCATs 414 and 1302, corresponding to the European and Asiatic coasts of the Aegean Sea, were merged. The boundary between COSCATs 1111 and 1112, at the southern edge of South America in the Pacific, was moved northward to account for the change in estuarine types from fjords to arheic (Dürr et al., 2011). In addition, all endorheic watersheds were excluded from the study. This includes the four COSCAT 
segments flowing into the Aral and Caspian seas (410, 13041306). The Antarctic continent, on the other hand, was incorporated using five new COSCATs (1501 to 1505). A map of all the COSCAT segments and their updated limits is provided as a Supplement.

The isobaths on continental shelves were extracted from 1 min resolution global bathymetries. The version 9.1 of the bathymetry of Smith and Sandwell (1997, updated in 2007, http://topex.ucsd.edu/marine_topo) was preferably used as it generally better represents very near shore coastal features (Dürr et al., 2011). However, its geographical coverage does not extend past $80^{\circ} \mathrm{N}$ and $\mathrm{S}$. Beyond this limit, the isolines were then extracted from the ETOPO 2 bathymetry (US Department of Commerce, National Oceanic and Atmospheric Administration, National Geophysical Data Center, 2006, http://www.ngdc.noaa.gov/mgg/fliers/06mgg01.html). In the Northern Hemisphere, this concerns the northern part of the Canadian archipelagos and Greenland as well as the Russian Arctic shelves. In the Southern Hemisphere, it only affects Antarctica. Ten isobaths were extracted for each COSCAT: $20 \mathrm{~m}, 50 \mathrm{~m}, 80 \mathrm{~m}, 120 \mathrm{~m}, 150 \mathrm{~m}, 200 \mathrm{~m}, 350 \mathrm{~m}, 500 \mathrm{~m}, 750 \mathrm{~m}$ and $1000 \mathrm{~m}$. After a conversion from grid data to vector polygons using GIS, the surface area and average water depth were calculated for each polygon. The aggregation of polygons for each COSCAT provides the surface area and the volume of a shelf segment comprised between two isobaths. Table 1 summarizes the globally integrated surface areas and volumes of the continental shelves for the succession of depth intervals.

For each COSCAT, the depth at which the shelf breaks was estimated by calculating the slope of the sea floor. The outer limit of the shelf was defined as the isobath for which the increase in slope is the maximum over the $0-1000 \mathrm{~m}$ interval, yet still inferior to $2 \%$. This value was selected as a compromise between the average slope and the upper continental slope of 0.5 and $3 \%$, respectively, although the latter varies between $1 \%$ and $10 \%$ (Gross, 1972; Pinet, 1996). Locally, some very irregular topographic features smaller than the spatial resolution of our bathymetric grid induced artefacts which required manual corrections based on geographic atlases (New York Times, 1992).

\subsection{MARCATS segmentation}

The coarsest segmentation (level III) aggregates COSCAT units into larger geographical boundaries whose limits account for oceanic features such as coastal currents or the boundaries of marginal seas. The resulting 45 units (Fig. 2), named MARCATS, are an aggregation of 3-4 COSCATs on average. Some MARCATS, however, correspond to one COSCAT only when their boundaries embrace a well-defined coastal current like the Leeuwin Current (MARCATS 33, LEE), which flows southward off the coast of Australia and differs in nature from adjacent COSCATs (Pearce, 1997). Other MARCATS are an aggregation of up to 10 COSCATs
Table 1. Global surface areas and volumes of coastal seas between various isobaths. The integrated values between the shore and the deepest isobaths are also provided.

\begin{tabular}{lrrrr}
\hline Depth $(\mathrm{m})$ & Surface $\left(10^{6} \mathrm{~km}^{2}\right)$ & Cumulative & Volume $\left(10^{6} \mathrm{~km}^{3}\right)$ & Cumulative \\
\hline $0-20$ & 4.969 & & 0.053 & \\
$20-50$ & 7.413 & 12.379 & 0.260 & 0.312 \\
$50-80$ & 5.100 & 17.480 & 0.330 & 0.643 \\
$80-120$ & 4.306 & 21.786 & 0.428 & 1.070 \\
$120-150$ & 2.124 & 23.909 & 0.287 & 1.358 \\
$150-200$ & 2.476 & 26.386 & 0.434 & 1.792 \\
$200-350$ & 4.550 & 30.937 & 1.234 & 3.026 \\
$350-500$ & 3.083 & 34.020 & 1.307 & 4.333 \\
$500-750$ & 3.401 & 37.421 & 2.098 & 6.432 \\
$750-1000$ & 2.417 & 39.838 & 2.113 & 8.545 \\
Total & 39.838 & & 8.545 & \\
\hline
\end{tabular}

in the case of a large marginal sea like the Mediterranean Sea (MARCATS 20, MED). Each MARCATS was attributed a type following Liu's classification of continental shelf seas (Liu et al., 2010). The different classes considered here are eastern boundary current $(\mathrm{EBC}, 1)$, western boundary current (WBC, 2), monsoon-influenced margins (3), sub-polar margins (4), polar margins (5), marginal seas (6), tropical margins (7).

Eastern and western boundary currents (1 and 2) are generated by large oceanic gyres when they flow parallel to the continents. The lateral water flow created by Ekman's current perpendicular to the boundary current induces upwelling of deeper waters, which sustain primary production where the upwelling flux is large enough (Atkinson et al., 2005). Monsoon-dominated margins (3) regroup all Indian Ocean coasts where the hydrodynamics are strongly driven by the seasonal wind patterns of the monsoon (Nag, 2010). Subpolar margins (4) are characterized by cool temperate waters located on latitudes higher than $50^{\circ} \mathrm{N}$ and lower than $30^{\circ} \mathrm{S}$ approximately. These limits are used to differentiate them from the polar margins (5), which explicitly refer to coastal waters surrounding the Arctic and Antarctic oceans. Marginal seas (6) refer to interior seas only comprising relatively shallow waters flowing on the continental shelf (Hudson Bay, Baltic Sea, Persian Gulf) or wider entities including deep waters (Gulf of Mexico, Mediterranean Sea, Sea of Japan, etc.). In the latter case, the MARCATS only cover the generally narrow shelves surrounding the main regional sea. An important characteristic of such marginal systems is a generally longer renewal rate of water compared to other systems directly connected to the open ocean (Meybeck and Dürr, 2009). Last, tropical margins (7) are typically warm coastal waters located in the tropics and form an equatorial belt around the Earth. The average temperature in such areas is high $\left(>18^{\circ} \mathrm{C}\right)$ all year long regardless of seasonality. Note that some coastal regions present characteristics corresponding to several classes. For instance, the Red Sea could arguably be defined as a marginal sea influenced by the monsoon. In such cases, a hierarchy of criteria was used to identify the dominant characteristic. The first criterion is the 


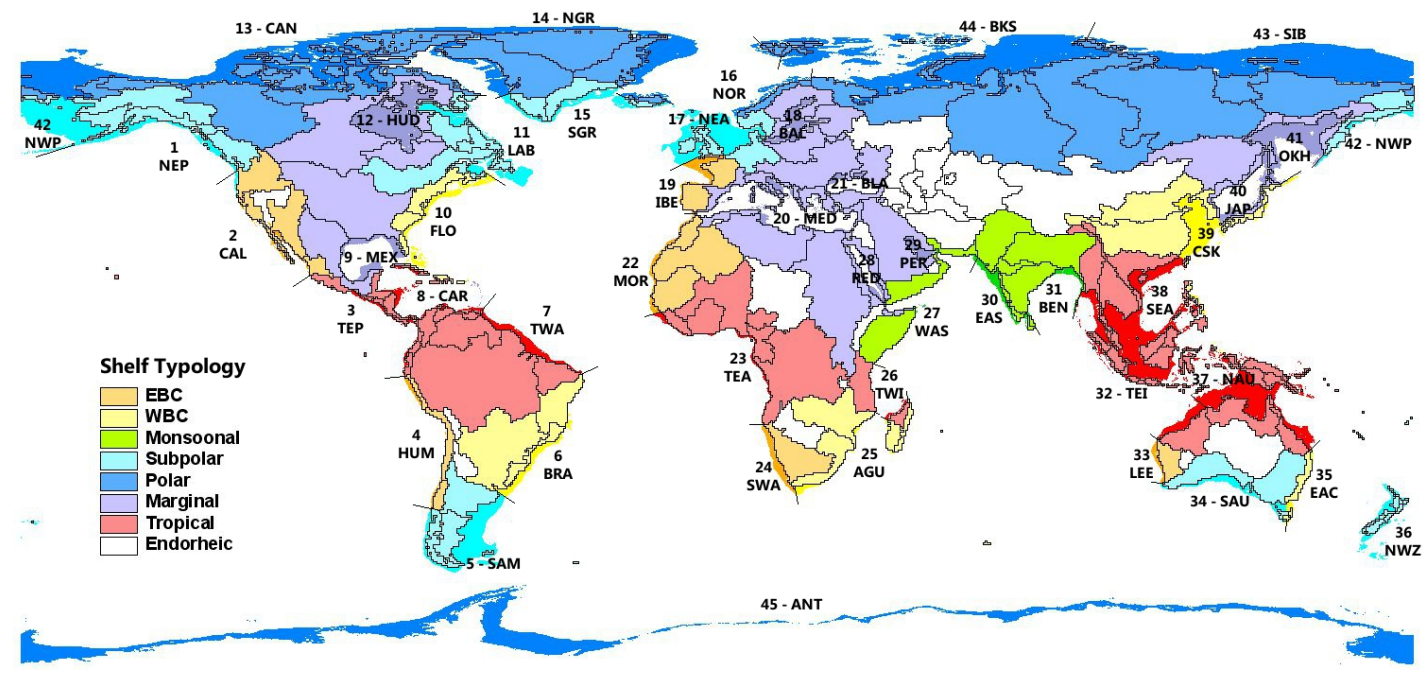

Fig. 2. Geographic limits of MARCATS and COSCAT segments with the typology of MARCATS.

occurrence or absence of EBC or WBC. Next, the presence of a marginal sea is used and, finally, monsoonal influence is applied. There is no overlap between the three remaining classes (tropical, polar and sub-polar).

\section{Results and discussion}

\subsection{MARCATS classification of continental shelves}

Figure 2 presents the location and surface area of the 45 MARCATS units. Table 2 lists all the MARCATS and their constitutive COSCATs for which the shelf break depth is also given. The limits of the individual COSCATs are also represented by black lines in Fig. 2. The colour code corresponds to the MARCATS classification, the continental shelves being highlighted in slightly darker colours. Note that the geographic projection used for this map over-represents the surface area of high latitude regions - this has been corrected for the surface area and volume calculations. EBC and WBC (in orange and yellow, respectively) border most continents at the mid-latitudes and account for a cumulative coastline of over $70000 \mathrm{~km}$. The major upwelling regions (California, Morocco, Canary, Humboldt, etc.) are driven by EBC or WBC; yet these currents generally follow the continents over much larger distances than those corresponding to the area where upwelling is intense (Longhurst, 1995; Xie and Hsieh, 1975). In the Pacific, the MARCATS 2 (CAL) and 4 (HUM) exemplify this feature. They comprise five and three COSCATs, respectively, while in reality, only one COSCAT covers the high intensity upwelling area (COSCAT 805 for the California Current and COSCAT 1114 for the Humboldt Current, Table 2). The California Current, for instance, is a part of the North Pacific Gyre, which extends up to the latitude corresponding to British Columbia in Canada (Karl, 1999; Mann and Lazier, 2006), although the upwelling is induced along the south-western coast of the United States. In the Atlantic, Northern Hemisphere EBCs are located in the zone along Senegal to the Iberian Peninsula, and produce the Morocco (MARCATS 22, MOR) and Portugal upwellings (MARCATS 19, IBE). In the Southern Hemisphere, the EBC is located off the coast of Namibia (Benguela Current, MARCATS 24, SWA). The only EBC in the Indian Ocean is the Leeuwin Current, located along the western border of Australia (MARCATS 33, LEE). The distribution of WBCs essentially mirrors that of EBCs on the opposite side of the oceans. In the Pacific Ocean, South East Asia is bordered by a WBC in the north (MARCATS 39, CSK) and the south (MARCATS 35, EAC). In the Atlantic, the Brazilian (MARCATS 6, BRA) and the Florida currents (MARCATS 10, FLO) are the pair of WBCs, one per hemisphere. Finally, in the Indian Ocean, the southern tip of Africa is associated with the Agulhas Current, which flows from Madagascar to Cape Town (MARCATS 25, AGU).

Margins under monsoonal influence (green) account for about half of the length of the shelves in the Indian Ocean, forming a $20000 \mathrm{~km}$ long arc running from the coast of Somalia (MARCATS 27, WAS) to the Bay of Bengal (MARCATS 31, BEN), which also includes all the coast of India (MARCATS 30, EAS). The main characteristic of this region is the seasonal inversion of wind patterns, affecting the climate as well as the direction and strength of coastal currents. As a consequence, the coast of Somalia is an area of upwelling in the summer (Longhurst, 1998) as this region is influenced by a seasonal boundary current which disappears during wintertime.

Subpolar margins (light blue) are found on all continents but Africa. They are located at relatively high latitudes (above 40-50 degrees) in regions where EBCs and WBCs fade out or drift away from the coasts. In the North Pacific, the subpolar margins lie along the western coast of Canada 
Table 2. List of the modified COSCAT segments with the depth of the outer limit of their continental shelves and the residence time of fresh water. COSCATs followed by a star $\left(^{*}\right)$ have been defined or modified for the purpose of the present work.

\begin{tabular}{|c|c|c|c|c|c|c|c|}
\hline MARCATS & COSCAT & $\begin{array}{r}\text { Shelf } \\
\text { Limit }(\mathrm{m})\end{array}$ & $\begin{array}{r}\text { Freshwater } \\
\text { Residence Time }(\mathrm{yr})\end{array}$ & MARCATS & COSCAT & $\begin{array}{r}\text { Shelf } \\
\text { Limit }(m)\end{array}$ & $\begin{array}{r}\text { Freshwater } \\
\text { Residence Time (yr) }\end{array}$ \\
\hline \multirow[t]{3}{*}{ 1-NEP } & 0809 & 350 & 29.6 & 18-BAL & 0404 & - & 110.1 \\
\hline & 0810 & 350 & 87.2 & & 0405 & - & 40.1 \\
\hline & 0811 & 500 & 1552.1 & & 0406 & - & 9.1 \\
\hline \multirow[t]{5}{*}{ 2-CAL } & 0804 & 150 & 42.2 & 19-IBE & 0401 & 350 & 172.4 \\
\hline & 0805 & 200 & 428.1 & & $0419^{*}$ & 350 & 62.1 \\
\hline & 0806 & 200 & 4340.1 & 20-MED & 0001 & 200 & 234.4 \\
\hline & 0807 & 200 & 33.7 & & 0002 & 150 & 3525.9 \\
\hline & 0808 & 350 & 12.5 & & 0003 & 150 & 8.3 \\
\hline \multirow[t]{5}{*}{ 3-TEP } & 0801 & 150 & 34.6 & & $0414^{*}$ & 150 & 162.0 \\
\hline & 0802 & 350 & 89.3 & & 0415 & 200 & 232.8 \\
\hline & 0803 & 80 & 4.9 & & 0416 & 350 & 76.7 \\
\hline & 1115 & 150 & 33.6 & & 0417 & 200 & 389.2 \\
\hline & 1116 & 150 & 5.7 & & 0418 & 200 & 69.6 \\
\hline \multirow[t]{3}{*}{ 4-HUM } & $1112^{*}$ & 350 & 43.5 & & $1301^{*}$ & 150 & 40.3 \\
\hline & 1113 & 200 & 239.8 & 21-BLA & 0411 & - & 13.0 \\
\hline & 1114 & 500 & 1044.3 & & 0412 & 350 & 19.4 \\
\hline \multirow{3}{*}{ 5-SAM } & 1109 & 350 & 367.5 & & 0413 & 350 & 593.0 \\
\hline & 1110 & 350 & 3502.1 & & 1103 & 150 & 2.8 \\
\hline & $1111^{*}$ & 500 & 142.8 & 22-MOR & 0019 & 150 & 24.5 \\
\hline \multirow[t]{3}{*}{ 6-BRA } & 1106 & 120 & 18.5 & & 0020 & 150 & 11722.1 \\
\hline & 1107 & 350 & 130.2 & & 0021 & 200 & 743.5 \\
\hline & 1108 & 350 & 9.8 & 23-TEA & 0014 & 150 & 162.0 \\
\hline \multirow[t]{3}{*}{ 7-TWA } & 1103 & 150 & 2.8 & & 0015 & 200 & 232.8 \\
\hline & 1104 & 200 & 1.8 & & 0016 & 350 & 76.7 \\
\hline & 1105 & 120 & 21.3 & & 0017 & 200 & 389.2 \\
\hline \multirow[t]{4}{*}{ 8-CAR } & 0830 & 120 & 9.3 & & 0018 & 200 & 69.6 \\
\hline & 0831 & 120 & 12.1 & 24-SWA & 0013 & 750 & 5613.6 \\
\hline & 1101 & 150 & 3.4 & 25-AGU & 0009 & 150 & 10.9 \\
\hline & 1102 & 350 & 155.1 & & 0010 & 120 & 15.8 \\
\hline \multirow[t]{3}{*}{ 9-MEX } & 0832 & 150 & 40.6 & & 0011 & 120 & 4.8 \\
\hline & 0833 & 200 & 74.0 & & 0012 & 350 & 421.0 \\
\hline & 0834 & 120 & 11.6 & 26-TWI & 0007 & 120 & 3.1 \\
\hline \multirow[t]{3}{*}{ 10-FLO } & 0826 & 150 & 261.2 & & 0008 & 150 & 11.2 \\
\hline & 0827 & 150 & 75.2 & 27-WIB & 0005 & 120 & 1409.9 \\
\hline & 0828 & 120 & 41.9 & & 0006 & 150 & 97.4 \\
\hline \multirow[t]{4}{*}{ 11-LAB } & 0821 & 500 & 164.4 & & 1341 & 150 & 3678.4 \\
\hline & 0822 & 120 & 57.3 & 28-RED & 0004 & 150 & 762.0 \\
\hline & 0824 & 120 & 14.7 & & 1344 & 150 & 41071.0 \\
\hline & 0825 & 150 & 12.9 & 29-PER & 1342 & - & 135.6 \\
\hline \multirow[t]{4}{*}{ 12-HUD } & 0817 & - & 226.9 & 30-EIB & 1338 & 150 & 48.8 \\
\hline & 0818 & - & 8.6 & & 1339 & 200 & 64.3 \\
\hline & 0819 & - & 375.8 & & 1340 & 200 & 86.1 \\
\hline & 0820 & - & 531.6 & 31-BEN & 1336 & 350 & 6.8 \\
\hline \multirow[t]{4}{*}{ 13-CAN } & 0814 & 150 & 2055.4 & & 1337 & 150 & 13.4 \\
\hline & 0815 & 120 & 24.6 & 32-TEI & 1334 & 150 & 29.7 \\
\hline & 0816 & 500 & 2596.8 & & 1335 & 200 & 18.6 \\
\hline & 0823 & 80 & - & & 1414 & 200 & 620.8 \\
\hline \multirow[t]{3}{*}{ 14-NGR } & 0501 & 500 & 2808.0 & 33-LEE & 1413 & 350 & 848.5 \\
\hline & 0502 & 500 & 1960.0 & $34-\mathrm{SAU}$ & 1411 & 350 & 261.1 \\
\hline & 0505 & 500 & 1367.9 & & 1412 & 350 & 2163.1 \\
\hline \multirow[t]{2}{*}{ 15-SGR } & 0503 & 500 & 1369.9 & 35-EAC & 1410 & 350 & 181.8 \\
\hline & 0504 & 500 & 166.7 & 36-NWZ & 1406 & 200 & 87.8 \\
\hline 16-NOR & 0407 & 200 & 92.4 & & 1407 & 350 & 282.7 \\
\hline \multirow[t]{2}{*}{ 17-NEA } & 0402 & 350 & 371.8 & & 1408 & 350 & 43.7 \\
\hline & 0403 & 200 & 113.0 & & 1409 & 350 & 81.1 \\
\hline
\end{tabular}


Table 2. Continued.

\begin{tabular}{|c|c|c|c|c|c|c|c|}
\hline MARCATS & COSCAT & $\begin{array}{r}\text { Shelf } \\
\text { Limit }(m)\end{array}$ & $\begin{array}{r}\text { Freshwater } \\
\text { Residence Time (yr) }\end{array}$ & MARCATS & COSCAT & $\begin{array}{r}\text { Shelf } \\
\text { Limit }(m)\end{array}$ & $\begin{array}{r}\text { Freshwater } \\
\text { Residence Time (yr) }\end{array}$ \\
\hline \multirow[t]{7}{*}{ 37-NAU } & 1330 & 150 & 35.2 & 42-NWP & 0812 & 350 & 321.8 \\
\hline & 1333 & 200 & 52.5 & & 1314 & 350 & 518.3 \\
\hline & 1401 & 200 & 7.7 & & 1315 & 350 & 195.5 \\
\hline & 1402 & 150 & 14.1 & & 1316 & 500 & 108.0 \\
\hline & 1403 & 500 & 88.7 & 43-SIB & 1309 & 150 & 13.7 \\
\hline & 1415 & 350 & 252.4 & & $1310^{*}$ & 150 & 261.0 \\
\hline & 1416 & 150 & 31.7 & & $1311^{*}$ & 500 & 352.4 \\
\hline \multirow[t]{4}{*}{ 38-SEA } & 1328 & 200 & 40.2 & & $1312^{*}$ & 150 & 1563.2 \\
\hline & 1329 & 200 & 46.9 & & 1313 & 500 & 1697.0 \\
\hline & 1331 & 150 & 23.1 & 44-BKS & 0408 & 200 & 196.9 \\
\hline & 1332 & 350 & 98.6 & & 0409 & 200 & 3477.7 \\
\hline \multirow[t]{5}{*}{ 39-CSK } & 1322 & 500 & 192.5 & & 1307 & 500 & 97.6 \\
\hline & 1323 & 150 & 24.4 & & 1308 & 500 & 61.0 \\
\hline & 1324 & - & 517.5 & 45-ANT & $1501^{*}$ & 1000 & - \\
\hline & 1325 & - & 42.8 & & $1502^{*}$ & 750 & - \\
\hline & 1326 & 350 & 35.4 & & $1503^{*}$ & 1000 & - \\
\hline \multirow[t]{2}{*}{ 40-JAP } & 1320 & 350 & 89.8 & & $1504^{*}$ & 1000 & - \\
\hline & 1321 & 500 & 223.8 & & $1505^{*}$ & 1000 & - \\
\hline \multirow[t]{3}{*}{ 41-OKH } & 1317 & 750 & 1360.0 & & & & \\
\hline & 1318 & 500 & 84.7 & & & & \\
\hline & 1319 & 500 & 569.5 & & & & \\
\hline
\end{tabular}

and South Alaska (MARCATS 1, NEP) and on the eastern face of Russia (MARCATS 42, NWP). The southern portion of South America is also considered sub-polar and extends from the northernmost fjords of Chile on the Pacific side to the Río de la Plata on the Atlantic side (MARCATS 5, SAM). A large fraction of the North Atlantic is bordered by subpolar shelves including the Labrador Sea (MARCATS 11, LAB), southern Greenland (MARCATS 15, SGR) and northwestern Europe (MARCATS 17, NEA). The latter comprises southern Iceland, as well as the Irish, Celtic and North seas. On the antipodes, southern Australia (MARCATS 34, SAU) and New Zealand (MARCATS 36, NWZ) complete the world distribution of subpolar margins.

Polar margins (deep blue) are located at very high latitudes of the Northern Hemisphere and include the Canadian archipelagos (MARCATS 13, CAN), northern Greenland (MARCATS 14, NGR), the Norwegian Basin (MARCATS 16, NOR) and the Russian Arctic Ocean (MARCATS 43, SIB and 44, BKS). In the Southern Hemisphere, the Antarctic continent is bordered by the polar MARCATS 45 (ANT).

In our classification, marginal seas (purple) include all enclosed and semi-enclosed shelves. All of them are located in the Northern Hemisphere, and they can be subdivided into two broad categories. The first category consists of the shelves bordering large deep oceanic basins such as the Gulf of Mexico (MARCATS 9, MEX), the Sea of Japan (MARCATS 40, JAP) and the Sea of Okhotsk (MARCATS 41, OKH). The Black Sea (MARCATS 21, BLA), the Mediterranean Sea (MARCATS 20, MED) and the Red Sea
(MARCATS 28, RED) also consist of narrow shelves surrounding deeper waters, but, in addition, they are characterized by a very limited connection to the ocean. In spite of being defined as a marginal sea, the influence of monsoon wind patterns can be observed in the hydrodynamics of the southern Red Sea (Al-Barakati et al., 2002). The other category of marginal seas consists of inner continental bodies of relatively shallow waters such as the Hudson Bay (MARCATS 12, HUD), the Baltic Sea (MARCATS 18, BAL) and the Persian Gulf (MARCATS 29, PER).

The remaining margins are located between both tropics (red). They are aligned in a sort of equatorial belt around the Earth and include the Pacific and Atlantic coasts of Central America (MARCATS 3, TEP and MARCATS 7, TWA), the Caribbean Sea (MARCATS 8, CAR), the Atlantic and Indian coasts of central Africa (MARCATS 23, TEA, and 26, TWI) as well as a large section of Oceania running from the north of Australia to the south of China and comprising most of Indonesia and the Philippines (MARCATS 37, NAU).

\subsection{Global importance of the continental margins}

Table 1 provides global values for sea surface areas and water volumes between the different isobaths used in this study. The global surface area of $26 \times 10^{6} \mathrm{~km}^{2}$ between the coastline and the $200 \mathrm{~m}$ isobath (the commonly used outer limit for the coastal ocean in global studies, Walsh, 1988; Borges et al., 2005) is similar to that of Laruelle et al. (2010). Yet, the distribution of this area among depth intervals indicates that the portion shallower than $80 \mathrm{~m}$ contributes to $17 \times 10^{6} \mathrm{~km}^{2}$. 
A significant fraction of the continental margins thus corresponds to shallow coastal waters such as the wide North Sea (COSCAT 404), and the Patagonian and Arctic continental shelves. The latter two exhibit highly extended shallow surface areas $(<200 \mathrm{~m})$ followed by a gentle slope and a deep shelf break.

Most coastal ocean surface area evaluations yield values in the range $25-30 \times 10^{6} \mathrm{~km}^{2}$ (Laruelle et al., 2010; Walsh, 1988; Cai et al., 2006; Chen and Borges, 2009), which corresponds to $8 \%$ of the world's ocean. These values have been largely used in the literature to constrain global budgets and box models (Borges et al., 2005; Laruelle et al., 2009, 2010; Mackenzie et al., 1993; Rabouille et al., 2001; Ver, 1998; Wanninkhof et al., 2013), but the use of surface areas varying by $20 \%$ from one study to another has implications regarding the accuracy of the budgets calculated. The common definition of a single proper limit for the outer edge of the continental shelf remains a matter of debate in the literature (Borges et al., 2005; Laruelle et al., 2010; Liu et al., 2010), and the choice of this limit depends not only on various sedimentological and morphological criteria, but also, to some degree, on convenience of use. Convenience is the main reason why the $200 \mathrm{~m}$ isobath has often been selected as it provides a consistent limit which is easy to manipulate and allows for intercomparability between studies. However, the morphological heterogeneity of the coastal zone cannot be accounted for by such a simple boundary. Liu et al. (2010) proposed a definition based on the increase in slope of the continental shelf as an alternative, which is also used here (see Sect. 2.1) and, although our estimate of $30 \times 10^{6} \mathrm{~km}^{2}$ falls within the range of previously reported values, the method allows for a more rigorous regional analysis of the shelf area distribution around the globe. The shelf break depths for each COSCAT are provided in Table 2. Furthermore, the surface areas and volumes between the calculated isobaths for all COSCAT segments are available as supplementary material as well as GIS files providing the exact geographic extent of each unit. This allows for comparisons between studies relying on different definitions for the boundary between the open and the coastal ocean. It also provides a clear boundary for oceanic studies which either exclude the coastal zone (Takahashi et al., 2009) or treat it differently from the open ocean (Wanninkhof et al., 2013).

The integrated volume of all continental shelves, from the shore to the shelf break, is $3860 \times 10^{3} \mathrm{~km}^{3}$ (for a surface area of $30 \times 10^{6} \mathrm{~km}^{2}$ ). Most continental shelves break at water depths between $150 \mathrm{~m}$ and $350 \mathrm{~m}$ (Fig. 3). The deeper shelves are found in polar and sub-polar regions, and their integrated volume accounts for more than half of the world's total volume of the coastal ocean. This includes the shelves of Antarctica, which are very deep and extend down to $1000 \mathrm{~m}$. Such particularity is a result of the downwarping caused by the weight of the ice sheet on the continent, glacial erosion and the lack of sedimentation from fluvial discharge (Anderson, 1999). It also includes the very wide Arctic

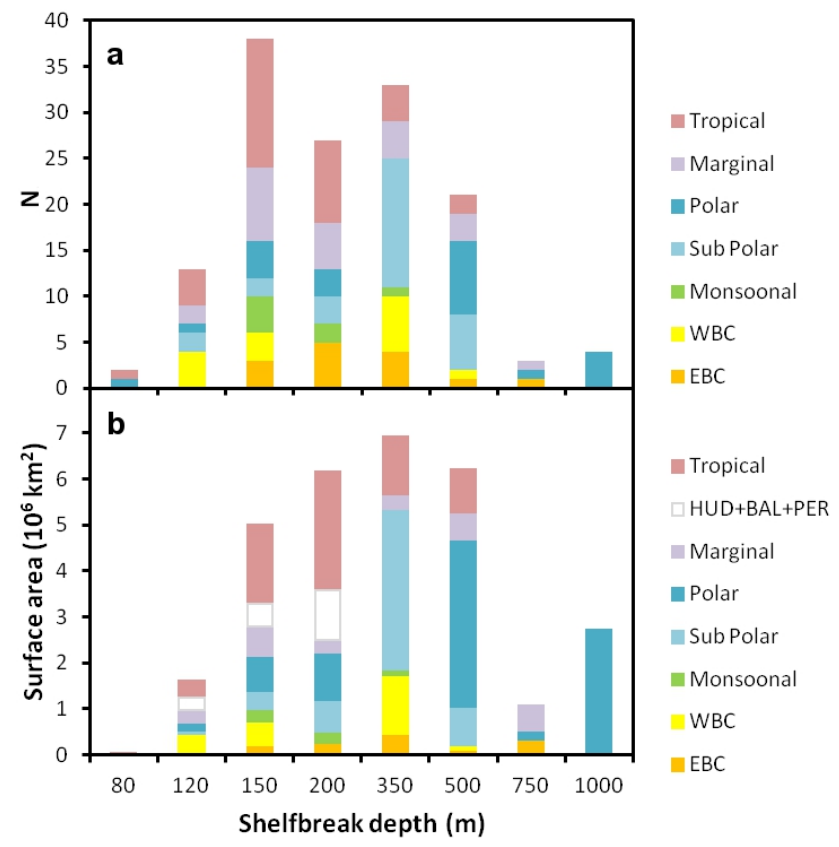

Fig. 3. Repartition of the depth at which the shelf breaks for each COSCAT segment (top, $\mathbf{a}$ - number $(N)$ of COSCAT segments per shelfbreak depth) and integrated surface area of continental shelves (bottom). The colour code represents the type of MARCATS.

shelves. Tropical shelves are generally shallower whereas shelves in contact with EBCs and WBCs do not exhibit a clear trend. Regions under monsoonal influence all have a shelf limit between $150 \mathrm{~m}$ and $350 \mathrm{~m}$. Internal marginal seas such as the Hudson Bay, the Baltic Sea and the Persian Gulf (HUD, BAL and PER) are relatively shallow and are entirely comprised within the continental platform. Therefore, they do not break and are not included in the accounting of COSCATs in Fig. 3a. In Fig. 3b, HUD, BAL and PER were assigned to the range corresponding to their maximum water depth, excluding any highly localized deep features $(<5 \%$ of surface area). The bulk of this distribution consists of relatively deep shelves. This is explained, in part, by the significant contribution of the deep Arctic shelves which amount to $5 \times 10^{6} \mathrm{~km}^{2}$ alone. It also indicates that many shallow shelves are relatively narrow. This is particularly striking for EBCs, which only represent a total surface area of $1.2 \times 10^{6} \mathrm{~km}^{2}$ and, to a lesser extent, WBCs with a total surface area of $2.9 \times 10^{6} \mathrm{~km}^{2}$.

\subsection{Connecting MARCATS with the continents}

Table 3 summarizes the surface areas of watersheds, estuaries and continental shelves for every MARCATS. The surface areas of watersheds and continental shelves are also compared with published values for the North Sea, Baltic Sea, Hudson Bay and Persian Gulf (Table 4). The consistency between our estimates and literature data is fairly good, and 
the discrepancy never exceeds $3 \%$. Table 4 also provides comparison between reported values and our estimates for the continental shelf volumes. Only $2 \%, 5 \%$ and $6 \%$ deviation are obtained for BAL, HUD and PER, respectively. The discrepancy reaches $15 \%$ in the case of the North Sea (COSCAT 403), but this is likely due to the use of a slightly different geographic definition of the extent of the North Sea in Thomas et al. (2005), which includes a very deep trench located on the eastern side. The surface areas of estuarine systems are based on a spatially explicit typology consisting of four different types of active estuarine filters and three types where estuarine filtering is absent (Dürr et al., 2011). Type I consists of small deltas and miscellaneous secondary streams or transitional systems which exhibit very limited filtering capacities. Type II regroups all estuaries and embayments dominated by tidal forcing. This includes not only all macro-tidal estuaries and bays but also most rias and many meso-tidal systems like those found in South Atlantic America and Siberia. Type III represents lagoons and enclosed estuaries, relatively protected from tidal influence (Schwartz, 2005). Type IV comprises fjords, fjaerds and other miscellaneous high latitudes systems generally characterized by deep waters and very long freshwater residence time. Large rivers (Type V) often produce an estuarine plume that protrudes past the conventional geographical limits of estuaries and, sometimes, even of continental shelves (McKee et al., 2004). To attribute a surface area to each estuarine type within each MARCATS, the respective length of each estuarine class is multiplied by an average ratio of estuarine surface per $\mathrm{km}$ of coastline following the procedure of Dürr et al. (2011). The distribution of estuarine types varies widely amongst the different classes of MARCATS. The polar margins in the Northern Hemisphere contribute $31 \%$ to the estuarine surface areas $\left(10^{6} \mathrm{~km}^{2}\right)$. These estuaries are heavily dominated by fjords (Fig. 4a). Antarctica does not have any estuary according to this calculation because the few rivers are essentially meltwater streams (Anderson, 1999; Jacobs et al., 1992).

The world's exorheic watershed surface totals $113 \times$ $10^{6} \mathrm{~km}^{2}$, which is 4 times larger than that of continental shelves and more than 100 times that of estuaries (Fig. 4b). Naturally, the ratio between these surfaces significantly varies from one region to another as well as the estuarine distribution along the coast. The spatial distribution of estuarine systems is indicated in Fig. 5a-f. Generally, EBCs and WBCs are characterized by narrow shelves that are connected to much larger watersheds (Fig. 4b). Moreover, it can be observed that many EBCs and WBCs present relatively narrow watersheds too, in particular in the Pacific (CAL and HUM, Fig. 5a and b). The cumulative surface area of shelves under influence of boundary currents is $4.4 \times 10^{6} \mathrm{~km}^{2}$ only ( $14 \%$ of the world's total). The regional contributions vary widely from the very wide China Sea (CSK) on the one hand to the very narrow coastal ribbon following South America in the South Pacific on the other hand (HUM). In the Atlantic, the

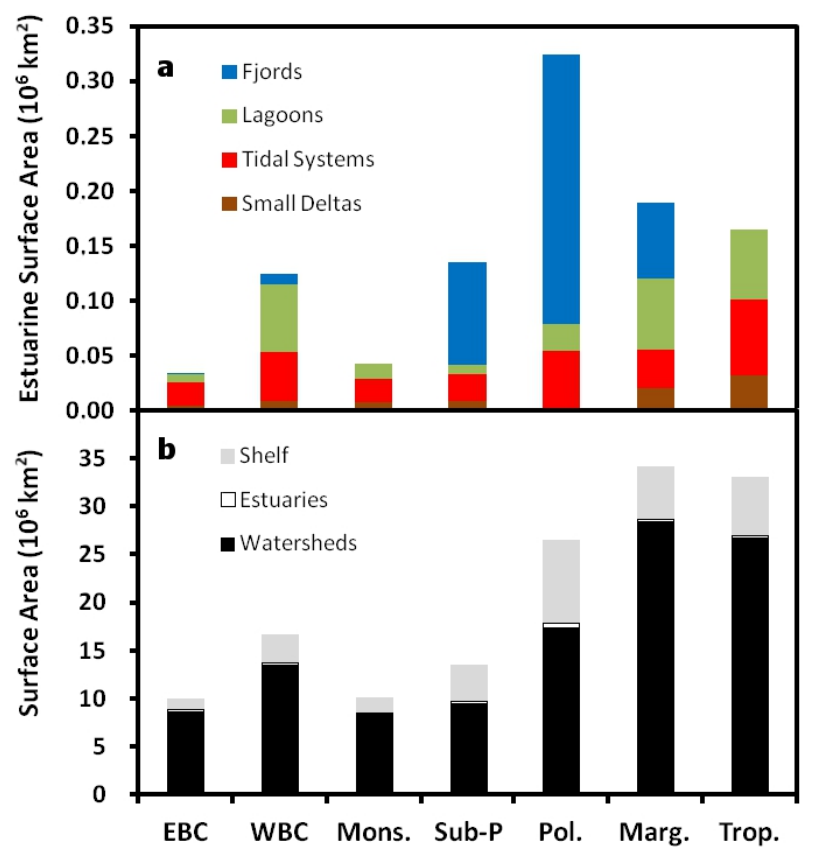

Fig. 4. Integrated surface areas for each MARCATS class of the different estuarine types (a) and watersheds, estuaries and continental shelf (b).

coasts of Morocco (MOR) and Portugal (IBE) are also very narrow, while those of the eastern US (FLO), Brazil (BRA) and Namibia (SWA) extend over several tens of kilometres.

Margins under monsoonal influence are essentially located between the Equator and the Tropic of Cancer $\left(23^{\circ} \mathrm{N}\right)$. A large section of this coastline is dominated by arid regions, on the western side (WAS, Fig. 5d). The cumulative estuarine surface area in these regions is only $43 \times 10^{3} \mathrm{~km}^{2}$, consisting mostly of small deltas located on the Indian sub-continent (EAS, Fig. 5d). The shelves are generally narrow while several watersheds are very large, in particular those flowing into the Bay of Bengal (BEN, Fig. 5e) like those of the GangesBrahmaputra, Godavari and Krishna rivers.

Subpolar margins present a wide diversity of profiles with extended shallow shelves (North Sea, NEA, Patagonian shelf, SAM) as well as fragmented archipelagos (Labrador Sea). Their cumulative watershed area amounts to $9.5 \times$ $10^{6} \mathrm{~km}^{2}$, and the ratio of watershed to shelf surface varies from 1 in New Zealand (NWZ) to 8 in the Labrador Sea (LAB) with an average value of 2.4. Estuaries in sub-polar regions essentially consist of tidal systems and fjords at the highest latitudes (NWP, NEP, Fig. 5a).

Polar margins are very wide as well as deep and account for over $50 \%$ of the volume of the coastal ocean and $29 \%$ of its surface area (Fig. 4). Although these systems include watersheds of several very large Russian rivers $(\mathrm{Ob}$, Yenisei, Lena, Amur, etc.), the average watershed to shelf ratio is only 2, the lowest amongst the classes of margins. Most of the fjords of the world are located in polar regions and, while they represent $40 \%$ of the world's estuarine surface area 
Table 3. List of the MARCATS segments with their type, the surface area of their various components, the freshwater discharge and the volume of their continental shelves.

\begin{tabular}{|c|c|c|c|c|c|c|c|c|}
\hline Number & System Name & Symbol & Class & $\begin{array}{l}\text { Estuarine Surface } \\
\qquad\left(10^{3} \mathrm{~km}^{2}\right)\end{array}$ & $\begin{array}{r}\text { Watershed Surface } \\
\qquad\left(10^{3} \mathrm{~km}^{2}\right)\end{array}$ & $\begin{array}{r}\text { Shelf Surface } \\
\left(10^{3} \mathrm{~km}^{2}\right)\end{array}$ & $\begin{array}{r}\text { Freshwater } \\
\text { Discharge }\left(\mathrm{km}^{3} \mathrm{yr}^{-1}\right)\end{array}$ & $\begin{array}{r}\text { Shelf Volume } \\
\left(\mathrm{km}^{3}\right)\end{array}$ \\
\hline 1 & North-eastern Pacific & NEP & Subpolar & 33.9 & 919 & 461 & 785 & 58932 \\
\hline 2 & California Current & CAL & EBC & 8.9 & 1781 & 214 & 428 & 16668 \\
\hline 3 & Tropical Eastern Pacific & TEP & Tropical & 6.2 & 638 & 198 & 586 & 15777 \\
\hline 4 & Peruvian Upwelling Current & HUM & EBC & 4.2 & 725 & 143 & 120 & 19769 \\
\hline 5 & South America & SAM & Subpolar & 22.0 & 1917 & 1230 & 289 & 141652 \\
\hline 6 & Brazilian Current & BRA & WBC & 26.3 & 4624 & 521 & 1117 & 36214 \\
\hline 7 & Tropical Western Atlantic & TWA & Tropical & 13.4 & 9242 & 517 & 8981 & 20691 \\
\hline 8 & Caribbean Sea & CAR & Tropical & 26.2 & 1109 & 344 & 941 & 15721 \\
\hline 9 & Gulf of Mexico & MEX & Marginal Sea & 31.9 & 5411 & 544 & 1085 & 22432 \\
\hline 10 & Florida Upwelling & FLO & WBC & 34.0 & 1130 & 858 & 531 & 50522 \\
\hline 11 & Sea of Labrador & LAB & Subpolar & 36.1 & 2351 & 395 & 1080 & 43178 \\
\hline 12 & Hudson Bay & HUD & Marginal Sea & 39.0 & 3601 & 1064 & 666 & 105267 \\
\hline 13 & Canadian Archipelagos & CAN & Polar & 163.7 & 3725 & 1177 & 382 & 157543 \\
\hline 14 & Northern Greenland & NGR & Polar & 24.1 & 373 & 614 & 82 & 139337 \\
\hline 15 & Southern Greenland & SGR & Polar & 8.8 & 101 & 270 & 108 & 60538 \\
\hline 16 & Norwegian Basin & NOR & Polar & 17.0 & 219 & 171 & 183 & 16915 \\
\hline 17 & North-eastern Atlantic & NEA & Marginal Sea & 37.6 & 1089 & 1112 & 498 & 101984 \\
\hline 18 & Baltic Sea & BAL & Marginal Sea & 26.3 & 1619 & 383 & 376 & 20165 \\
\hline 19 & Iberian Upwelling & IBE & $\mathrm{EBC}$ & 12.7 & 818 & 283 & 202 & 26640 \\
\hline 20 & Mediterranean Sea & MED & Marginal Sea & 15.1 & 8168 & 580 & 674 & 42224 \\
\hline 21 & Black Sea & BLA & Marginal Sea & 10.3 & 2411 & 172 & 360 & 8246 \\
\hline 22 & Moroccan Upwelling & MOR & $\mathrm{EBC}$ & 5.6 & 3637 & 225 & 125 & 11520 \\
\hline 23 & Tropical Eastern Atlantic & TEA & Tropical & 26.6 & 8394 & 284 & 2762 & 14786 \\
\hline 24 & South-western Africa & SWA & EBC & 1.7 & 1293 & 308 & 14 & 76289 \\
\hline 25 & Agulhas Current & $\mathrm{AGU}$ & WBC & 28.4 & 3038 & 254 & 657 & 19607 \\
\hline 26 & Tropical Western Indian & TWI & Tropical & 5.8 & 1022 & 72 & 328 & 2039 \\
\hline 27 & Western Arabian Sea & WAS & Indian Margins & 2.0 & 1723 & 102 & 26 & 5234 \\
\hline 28 & Red Sea & RED & Marginal Sea & 0 & 771 & 190 & 6 & 8101 \\
\hline 29 & Persian Gulf & PER & Marginal Sea & 2.3 & 2466 & 233 & 61 & 8296 \\
\hline 30 & Eastern Arabian Sea & EAS & Indian Margins & 14.5 & 1847 & 342 & 293 & 18823 \\
\hline 31 & Bay of Bengal & BEN & Indian Margins & 10.1 & 2934 & 230 & 1640 & 12888 \\
\hline 32 & Tropical Eastern Indian & TEI & Indian Margins & 16.2 & 2060 & 809 & 1324 & 48634 \\
\hline 33 & Leeuwin Current & LEE & $\mathrm{EBC}$ & 0.6 & 471 & 118 & 11 & 9707 \\
\hline 34 & Southern Australia & SAU & Subpolar & 13.1 & 2249 & 452 & 66 & 38307 \\
\hline 35 & Eastern Australian Current & EAC & WBC & 7.9 & 290 & 139 & 67 & 12149 \\
\hline 36 & New Zealand & NWZ & Subpolar & 7.3 & 265 & 283 & 340 & 36833 \\
\hline 37 & Northern Australia & NAU & Tropical & 40.5 & 3010 & 2463 & 2548 & 145236 \\
\hline 38 & South East Asia & SEA & Tropical & 45.6 & 3343 & 2318 & 2872 & 155848 \\
\hline 39 & China Sea and Kuroshio & CSK & WBC & 27.8 & 4401 & 1299 & 1594 & 125364 \\
\hline 40 & Sea of Japan & JAP & Marginal Sea & 6.7 & 418 & 277 & 252 & 40760 \\
\hline 41 & Sea of Okhotsk & $\mathrm{OKH}$ & Marginal Sea & 19.7 & 2472 & 992 & 539 & 199588 \\
\hline 42 & North-western Pacific & NWP & Subpolar & 22.3 & 1783 & 1082 & 363 & 82323 \\
\hline 43 & Siberian Shelves & SIB & Polar & 37.8 & 5041 & 1918 & 801 & 123368 \\
\hline 44 & Barents and Kara Seas & BKS & Polar & 72.2 & 7940 & 1727 & 1585 & 181707 \\
\hline 45 & Antarctic Shelves & ANT & Polar & - & - & 2952 & - & 1362298 \\
\hline
\end{tabular}

(Fig. 6), their cumulative contribution remains fairly small compared to the very wide Arctic shelves. Locally, however, they may contribute significantly to the surface area, as in the case of Norway where some of the largest and deepest fjords are located and where the shelf breaks only a few kilometres offshore. Here, fjords account for a surface area as high as $10 \%$ of that of the shelf.

Marginal seas, like sub-polar margins, do not exhibit a clear geomorphological pattern. An area of $28 \times 10^{6} \mathrm{~km}^{2}$ of watershed is connected to marginal seas, which amounts to $21 \%$ of the surface of the continents. Shallow internal seas (HUD, BAL, PER) have a very large surface area while most other marginal seas consist of narrow shelves collecting very large watersheds. This includes the Mississippi, the Nile and the Danube rivers, which discharge into the Gulf of Mexico (MEX), the Mediterranean Sea (MED) and the Black Sea
(BLA), respectively. The Sea of Okhotsk (OKH) is an exception as it is characterized by a wide shelf $\left(10^{6} \mathrm{~km}^{2}\right)$ connected to a relatively modest watershed of $2.4 \times 10^{6} \mathrm{~km}^{2}$.

Tropical margins are generally very narrow along the coasts of Africa (TEA and TWI) and America (TEP and TWA) and connected to some of the widest watersheds in the world (Amazon, Congo River, Niger). Their cumulative shelf surface area is $1.3 \times 10^{6} \mathrm{~km}^{2}$ for a cumulative watershed surface of $19.4 \times 10^{6} \mathrm{~km}^{2}$. Tropical margins in Oceania (TEI, NAU and SEA) display an opposite trend. The cumulative surface areas for shelves and watershed in this region are $4.9 \times 10^{6} \mathrm{~km}^{2}$ and $7.4 \times 10^{6} \mathrm{~km}^{2}$, respectively, yielding a ratio of 1.5. This is an order of magnitude lower than that of the other tropical margins, and the average ratio is thus on the order of 4. Generally, the tropical MARCATS do not exhibit very large estuaries because their coastline is either 

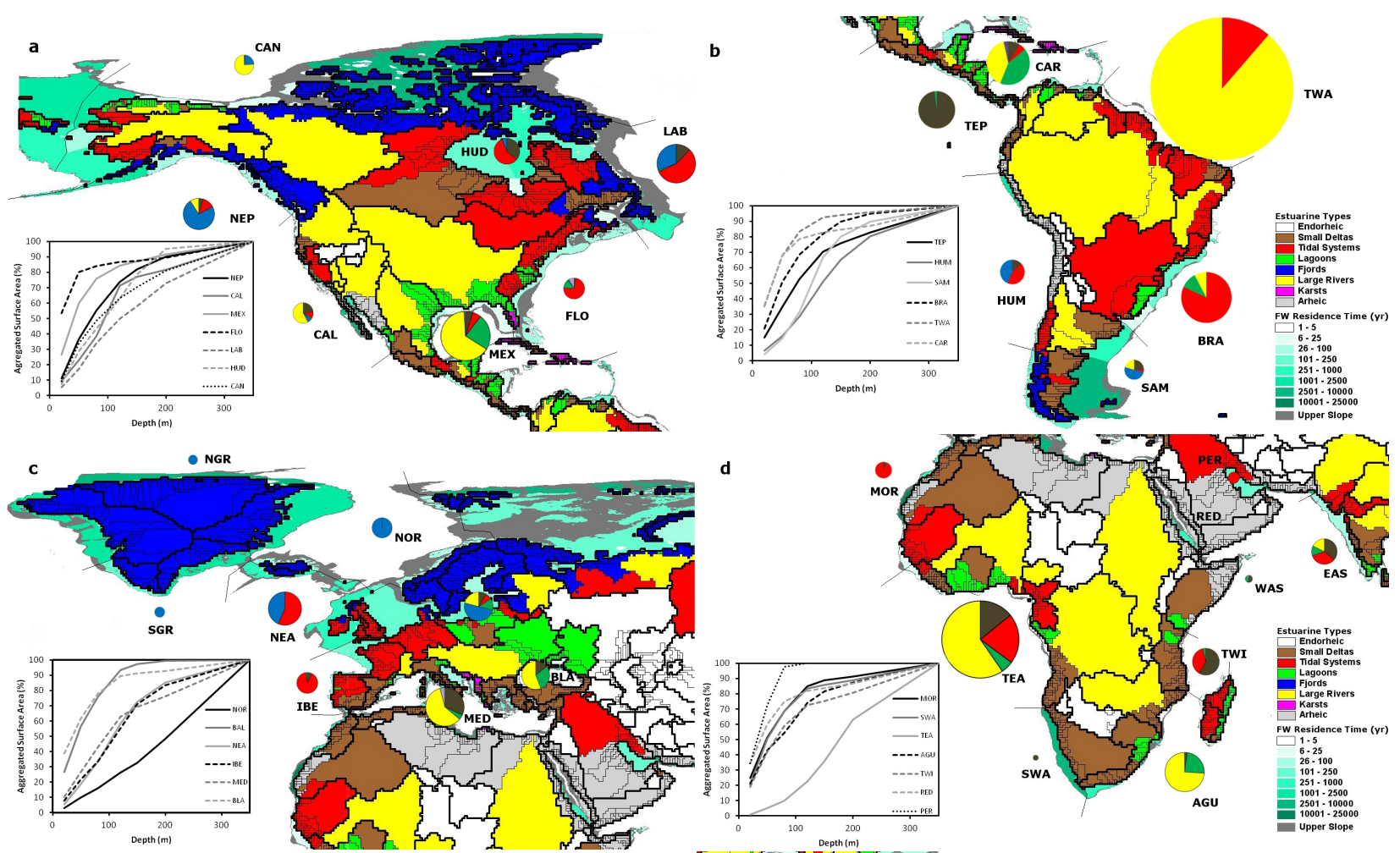

d
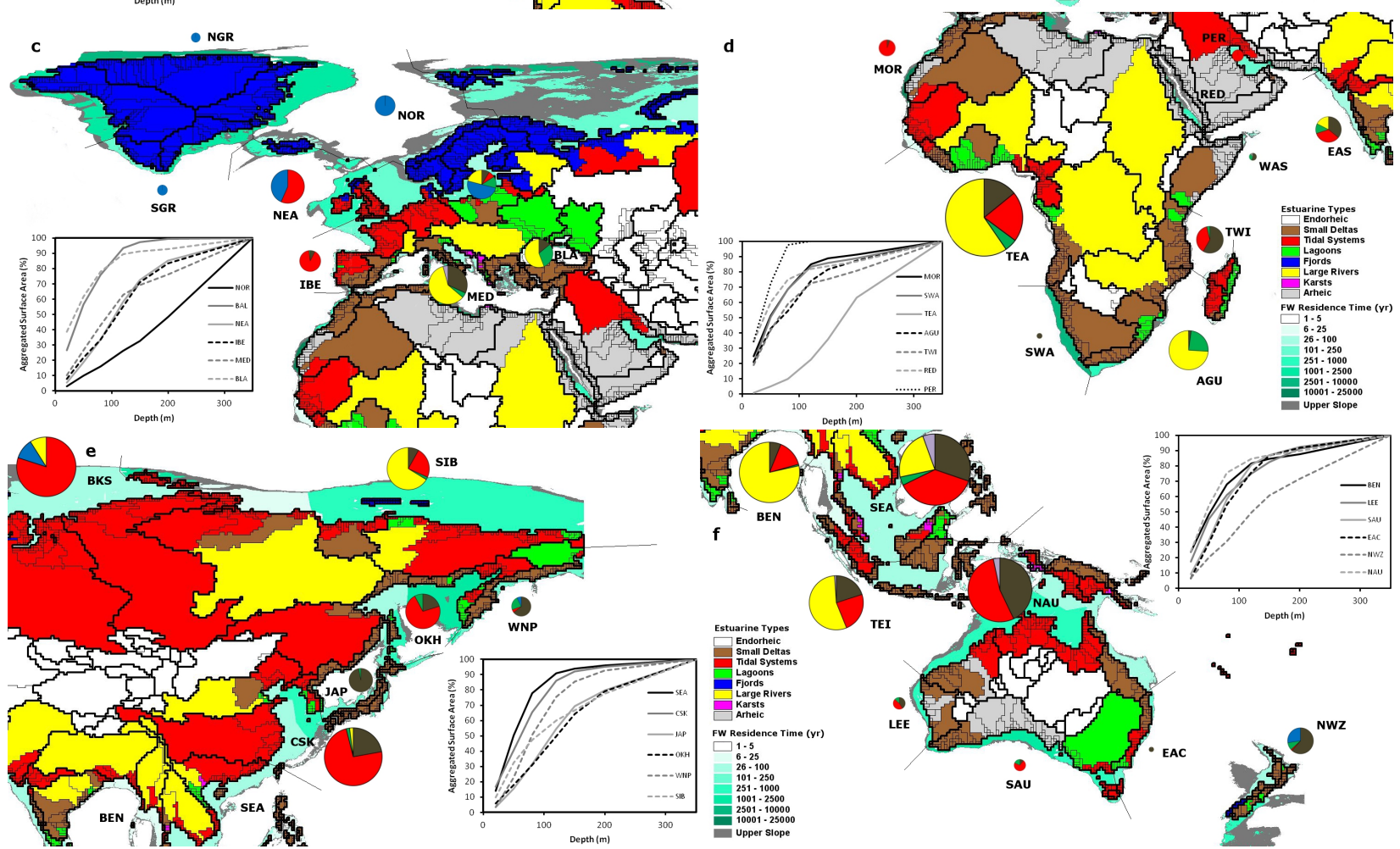

Fig. 5. Map representing the COSCAT segments (bold lines) and their corresponding continental shelf. The colour of the shelf indicates the freshwater residence time, and the grey area represents the geographic extent of the upper slope (from the shelf break until the $-1000 \mathrm{~m}$ isobaths). Within each COSCAT the limits of all watersheds are indicated at a 0.5 degree resolution, and the colour code indicates the type of estuarine filter at the interface between the river and the shelf. The limits of the MARCATS segments are indicated by the grey lines and, for each one, a pie chart represents the total freshwater discharge from rivers and its distribution amongst the different estuarine types. The size of the pie is proportional to the total water discharge for a given MARCATS. The panel provides the integrated surface area of the shelf with respect to the depth of its outer limit for each MARCATS segment.

dominated by small deltas or wide arheic regions (Dürr et al., 2011) where rivers do not flow constantly and occasional rain events create wadies rather than permanent estuaries. The latter is characteristic of regions such as, for example, the western coast of the Arabic Sea (WAS, Atroosh and Moustafa, 2012).

The cumulative surface area of MARCATS shelves integrated to the $350 \mathrm{~m}$ isobaths is shown in small panels on Fig. 5. The most common distribution displays a rapid increase in cumulative surface area up to isobaths 100$150 \mathrm{~m}$. At this depth, $80 \%$ of the total shelf area is accounted for, and the increase is then more progressive. However, some MARCATS possess distinct features with a slope that increases linearly with depth. They belong mainly to the polar and sub-polar classes (NOR, LAB, NWZ) or to boundary currents (FLO, HUM, TEA). The peculiar profile of MARCATS 23 (TEA) is strongly influenced by the deep coastal canyon created by the Congo River (Droz et al., 1996). Other 
Table 4. Comparison between published (bold) and calculated (this study, italic) watershed surface area, water discharge, continental shelf surface and volumes in the North Sea, Baltic Sea, Hudson Bay and Persian Gulf.

\begin{tabular}{lllll}
\hline System & $\begin{array}{l}\text { North Sea } \\
\text { COSCAT 403 }\end{array}$ & $\begin{array}{l}\text { Baltic Sea } \\
\text { MARCATS 18 }\end{array}$ & $\begin{array}{l}\text { Hudson Bay } \\
\text { MARCATS 12 }\end{array}$ & $\begin{array}{l}\text { Persian Gulf } \\
\text { MARCATS 29 }\end{array}$ \\
\hline $\begin{array}{l}\text { Watershed Surface } \\
\text { Area }\left(10^{3} \mathrm{~km}^{2}\right)\end{array}$ & $\mathbf{8 5 0}^{\text {a }} 870$ & $\mathbf{1 6 5 0}^{\text {a }} 1619$ & $\mathbf{3 7 0 0}^{\text {b }} 3601$ & n.a. \\
$\begin{array}{l}\text { Shelf Surface Area } \\
\left(10^{3} \mathrm{~km}^{2}\right)\end{array}$ & $\mathbf{5 7 5 . 3}^{\mathrm{c}} 592$ & $\mathbf{3 7 4 . 6}^{\text {d }} 383$ & $\mathbf{1 0 4 0}^{\mathrm{e}} 1064$ & $\mathbf{2 3 9}^{\mathrm{f}} 233$ \\
$\begin{array}{l}\text { Shelf Volume } \\
\left(10^{3} \mathrm{~km}^{3}\right)\end{array}$ & $\mathbf{4 2 . 3}^{\mathrm{c}} 36.3$ & $\mathbf{2 0 . 5}^{\text {d }} 20.1$ & $\mathbf{1 0 0}^{\mathrm{g}} 105$ & $\mathbf{8 . 8}^{\text {f }} 8.3$ \\
\hline
\end{tabular}

${ }^{\mathrm{a}}$ OSPAR (2010); ${ }^{\mathrm{b}}$ Déry and Wood (2005); ${ }^{\mathrm{c}}$ Thomas et al. (2005); ${ }^{\mathrm{d}}$ Wulff et al. (2001); ${ }^{\mathrm{e}}$ Macdonald and Kuzyk (2011); ${ }^{\text {f }}$ Pous et al. (2012); ${ }^{\mathrm{g}}$ Saucier et al. (2004).

significant exceptions to the typical hypsometric profile include the Baltic Sea (BAL), the Black Sea (BLA) and the Persian Gulf (PER). All are shallow marginal seas which do not exhibit a real shelf break.

\subsection{Water flows}

The annually averaged freshwater discharges into the coastal ocean were calculated for each COSCAT and MARCATS (Table 3). The data set used is GlobalNEWS2 (Mayorga et al., 2010) from an original compilation of Fekete et al. (2002). Within each MARCATS, the discharge flowing through each estuarine type is also calculated (Fig. 5). The well-known hotspots for freshwater discharge are easily identified: the Amazon region (TWA), the Congo region (TEA), the Bengal Bay fuelled by the Ganges-Brahmaputra River (BEN) and South East Asia/Oceania (TEI, NAU and SEA). All these regions are located in the tropics, and their segment is thus listed as tropical in Liu's classification except for BEN, which is under monsoon influence. Polar and subpolar regions do not provide as much fresh water, with the exception of MARCATS 44 (BKS) which collects the discharge of the Ob River. The Gulf of Mexico (MEX) is the only marginal sea that receives more than $10^{3} \mathrm{~km}^{3} \mathrm{yr}^{-1}$ of fresh water, and, to a large extent, this is due to the Mississippi River (Table 3). Together, the nine marginal systems contribute $13 \%$ to the world's river discharge.

In most segments fed by at least one large river, the freshwater input is largely dominated by its discharge (CAN, MEX, CAL, TWA, TEA, AGU, SIB, BEN, TEI). Similarly, regions where tidal estuaries are present tend to be dominated by these systems. This concerns, in particular, the Atlantic coast of the USA (LAB and FLO), the Brazilian Current (BRA), Western Europe (NEA and IBE), the Barents and Kara Seas (BKS), the Sea of Okhotsk (OKH), the Eastern China Sea (CSK) and northern Australia (NAU). Fjords are exclusively found at high latitudes (NEP, SAM, CAN, HUD, LAB, NGR, SGR, NEA, NOR, BAL, BKS, NWZ) and, although their integrated surface area is important, their freshwater flow is quite modest $(\sim 7 \%$ of the world total). Lagoons are found on most continents and all latitudes (Fig. 4) but, in terms of freshwater inputs, are only marginal contributors except in the Caribbean (CAR) and along the Gulf of Mexico (MEX) where they can be found along stretches of the coastline and intercept $\sim 40 \%$ of the riverine water discharge. Small deltas, on the other hand, can locally be the main estuarine type through which significant water flow is transported. They are mainly located in tropical and sub-tropical areas and contribute very actively to highly rheic regions like South East Asia and Oceania (SEA, TEI, NAU).

For each COSCAT and MARCATS, the ratio between the shelf volume and the corresponding riverine discharge has been calculated (Fig. 5a-f). Globally, the comparison between the volume of continental shelf seas $(3860 \times$ $10^{3} \mathrm{~km}^{3}$ ) and the annual freshwater input into the ocean $\left(39 \times 10^{3} \mathrm{~km}^{3} \mathrm{yr}^{-1}\right)$ yields an average value of $\sim 100$. However, this "freshwater residence time" is somewhat skewed by the very large contribution of Antarctic shelves to the total (Fig. 6). If they are excluded from the calculation, the freshwater residence time drops to $\sim 55 \mathrm{yr}$, which remains significantly higher than the average residence time of $\sim 8$ $10 \mathrm{yr}$ calculated on the basis of the exchange with the open ocean through upwelling fluxes (Brink et al., 1995; Rabouille et al., 2001; Ver, 1998). Therefore, our results reveal that the renewal of continental shelf waters by freshwater inputs is 5-7 times slower than through upwelling fluxes on average. It should however be noted that the globally averaged boxmodel calculations for upwellings fluxes do not account for the significant spatial and temporal variability in intensity of upwelling processes, which can locally renew coastal waters in just weeks (Gruber et al., 2011). Furthermore, neither the box model nor our calculations resolve the lateral transport by along-shore coastal currents. The ratio of freshwater discharge to continental shelf volume varies significantly from one region to the other, from $2 \mathrm{yr}$ (for COSCAT 1104 where the Amazon flows) to several thousands of years in many arid regions. Only 17 of the 149 COSCATs have freshwater residence times shorter than $10 \mathrm{yr}$, and the cumulative annual freshwater input of these 17 COSCAT segments amounts to 


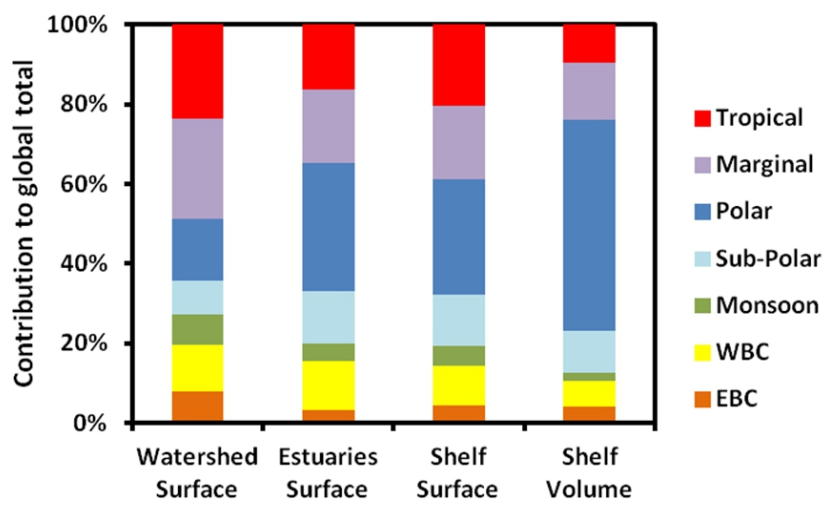

Fig. 6. Contribution of each MARCATS class to the global watershed surface area, estuarine surface area, continental shelf surface area and continental shelf volume.

$16 \times 10^{3} \mathrm{~km}^{3}$, which corresponds to $41 \%$ of the global water flux. These regions can be identified as coastal waters under strong riverine influence and bear resemblance, in that respect, to the RiOMARs, which are defined as continental margins where biogeochemical processes are dominated by riverine influences (McKee et al., 2004).

\section{5 $\mathrm{CO}_{2}$ outgassing from estuaries}

Globally, estuaries have been identified as net emitters of $\mathrm{CO}_{2}$ to the atmosphere (Abril and Borges, 2004; Borges, 2005; Borges et al., 2005; Cai, 2011; Chen and Borges, 2009; Laruelle et al., 2010). The first set of studies, based on simple upscaling from a few local measurements, provided first-order estimates of $\mathrm{CO}_{2}$ evasion ranging from 0.4 to 0.6 $\mathrm{Pg} \mathrm{C} \mathrm{yr}^{-1}$ (Abril and Borges, 2004; Borges, 2005; Borges et al., 2005; Chen and Borges, 2009). The more recent works by Laruelle et al. (2010) and Cai (2011) relying on a more detailed typology of estuarine systems have revised these estimates down to a value of $0.25 \pm 0.25 \mathrm{Pg} \mathrm{C} \mathrm{yr}^{-1}$ (Regnier et al., 2013). Yet, the best available global flux values remain largely uncertain because of the limited availability of measurements, their clustered spatial distribution and their biased representativeness. For instance, out of the 63 available local studies used by Laruelle et al. (2010), about $2 / 3$ are located in Europe or the US with only one value for fjord environments.

Here, we use the MARCATS segmentation in conjunction with a denser network of 161 local flux estimates to establish regionalized estuarine $\mathrm{CO}_{2}$ fluxes $\left(F \mathrm{CO}_{2}\right)$, at the global scale. A total of 93 local $F \mathrm{CO}_{2}$ estimates are used and complemented by 68 additional $F \mathrm{CO}_{2}$ values derived from estimates of the net ecosystem metabolism (NEM) reported by Borges and Abril (2012). For the latter, the linear $\mathrm{FCO}_{2}-$ NEM regression established by Maher and Eyre (2012) is used. The raw data are then clustered to derive a flux estimate for each estuarine type considered here (small deltas, tidal systems, lagoons, fjords). In MARCATS where at least two local studies are available for a given estuarine type $(n=14$,

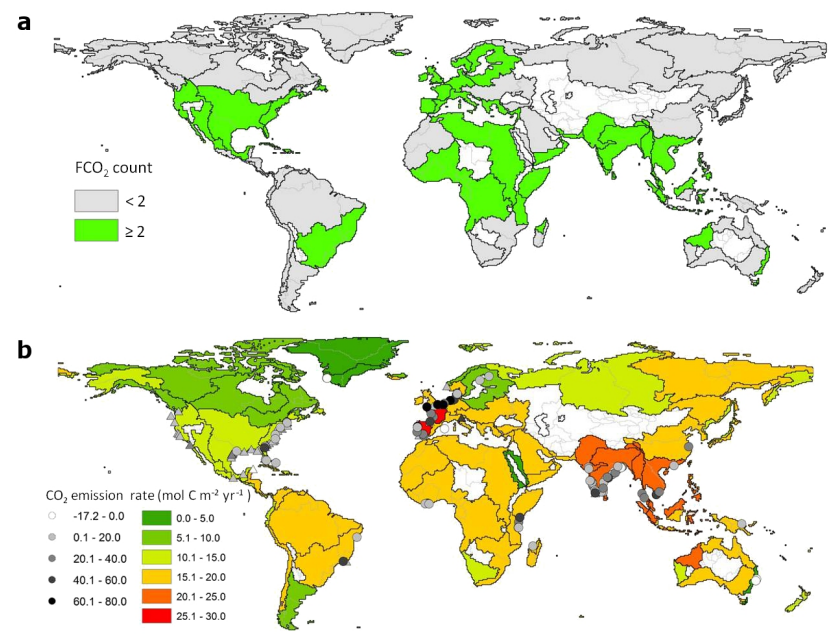

Fig. 7. (a) Number of local air-water $\mathrm{CO}_{2}$ flux estimates available per MARCATS (black lines), COSCAT limits are indicated by grey lines. (b) Air-water $\mathrm{CO}_{2}$ emission rates for estuaries from direct estimates (dots) and derived from net ecosystem metabolism (triangles). Mean rates per MARCATS are represented by the colour scale.

Fig. 7a), the emission rate is directly extrapolated from the measurements and the total surface area of the estuarine type within the given MARCATS (Table 5). Their cumulative surface area amounts to $184 \times 10^{3} \mathrm{~km}^{2}$, which corresponds to $17 \%$ of the world total for all types and $30 \%$ if only small deltas, tidal systems and lagoons are taken into account. For the other MARCATS $(n=31)$, the global area-specific average flux calculated for each type $\left(\overline{F \mathrm{CO}_{2}}\right.$, Table 5$)$ is used and multiplied by the type-specific estuarine surface-area for the corresponding MARCATS.

Estuaries in Western Europe (IBE, NEA) are dominated by heavily polluted tidal systems and are hotspots of $\mathrm{CO}_{2}$ emissions with average rates up to $28 \mathrm{~mol} \mathrm{C} \mathrm{m}^{-2} \mathrm{yr}^{-1}$ (Fig. 7b). European marginal seas, however, are characterized by lower values (BAL, MED). The region comprising the estuaries of India, Bangladesh and Indonesia (EAS, BEN, TEI) displays emission rates $>20 \mathrm{~mol} \mathrm{C} \mathrm{m}^{-2} \mathrm{yr}^{-1}$, but, because of a smaller estuarine surface area (Table 3 ), the total $\mathrm{CO}_{2}$ evasion from Indian estuaries is substantially lower than that of Western Europe ( 6.5 vs. $\left.13.4 \mathrm{Tg} \mathrm{C} \mathrm{yr}^{-1}\right)$, as also calculated by Sarma et al. (2012). The estuarine outgassing from the western, southern and eastern coasts of the US (CAL, MEX, FLO), derived from local $\mathrm{FCO}_{2}$, yields smaller values between 11.7 and $14.1 \mathrm{~mol} \mathrm{C} \mathrm{m}^{-2} \mathrm{yr}^{-1}$. Under warmer latitudes, BRA, TEA and TWI exhibit emission rates $>15 \mathrm{~mol} \mathrm{C} \mathrm{m}^{-2} \mathrm{yr}^{-1}$ while the eastern Australian coasts (EAC) display the lowest rate of any region $\left(3.0 \mathrm{~mol} \mathrm{C} \mathrm{m}^{-2} \mathrm{yr}^{-1}\right)$. This average is largely influenced by the estuaries studied by Maher and Eyre (2012), which are characterized by an intake of atmospheric $\mathrm{CO}_{2}$. 
Table 5. Air-water $\mathrm{CO}_{2}$ fluxes for each estuarine type based on field studies. Positive values represent a source of $\mathrm{CO}_{2}$ to the atmosphere. ${ }^{a}$ indicates a $\mathrm{CO}_{2}$ rate calculated from a NEM estimate and ${ }^{b}$ indicates sites used to derive regional averages. Global emissions per unit surface area based on direct $\mathrm{FCO}_{2}$ and derived from NEM lead to similar results for small deltas

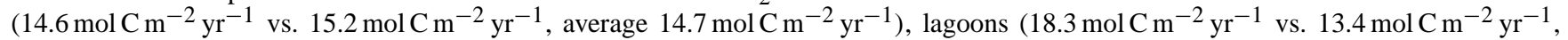
average $\left.15.1 \mathrm{~mol} \mathrm{C} \mathrm{m}^{-2} \mathrm{yr}^{-1}\right)$ and fjords $\left(5 \mathrm{~mol} \mathrm{C} \mathrm{m}^{-2} \mathrm{yr}^{-1} \mathrm{vs} .4 .9 \mathrm{~mol} \mathrm{C} \mathrm{m}^{-2} \mathrm{yr}^{-1}\right.$, average $\left.5.0 \mathrm{~mol} \mathrm{C} \mathrm{m}^{-2} \mathrm{yr}^{-1}\right)$. In the case of tidal systems, direct $\mathrm{FCO}_{2}$ estimates $\left(25 \mathrm{~mol} \mathrm{C} \mathrm{m}^{-2} \mathrm{yr}^{-1}\right)$ are $\sim 2-3$ times larger than NEM-derived estimates $\left(8.8 \mathrm{~mol} \mathrm{C} \mathrm{m}^{-2} \mathrm{yr}^{-1}\right)$ for an average of $15.1 \mathrm{~mol} \mathrm{C} \mathrm{m}^{-2} \mathrm{yr}^{-1}$. This bias is likely due to the dominance of polluted European estuaries in the $F \mathrm{CO}_{2}$ data set while the NEM-derived values are more homogeneously distributed (Maher and Eyre, 2012; Revilla et al., 2002).

\begin{tabular}{|c|c|c|c|c|c|}
\hline Site & MARCATS & Long. & Lat. & $\begin{array}{r}\overline{F \mathrm{CO}_{2}} \\
\left(\mathrm{~mol} \mathrm{C} \mathrm{m}{ }^{-2} \mathrm{yr}^{-1}\right)\end{array}$ & Reference \\
\hline \multicolumn{6}{|l|}{ Small deltas } \\
\hline Itacuraça Creek (BR) & 6 & -44 & -23 & 41.4 & Borges et al. (2003) \\
\hline Shark River (US) & 9 & -81.1 & 25.2 & 18.4 & Koné and Borges (2008) \\
\hline Duplin River (US) ${ }^{\mathrm{b}}$ & 10 & -81.3 & 31.5 & 21.4 & Wang and Cai (2004) \\
\hline Norman's Pond (BS) ${ }^{b}$ & 10 & -76.1 & 23.8 & 5.0 & Borges et al. (2003) \\
\hline Río San Pedro (ES) & 19 & -5.7 & 36.6 & 39.4 & Ferrón et al. (2007) \\
\hline Kidogoweni Creek $(\mathrm{KE})^{\mathrm{b}}$ & 26 & 39.5 & -4.4 & 23.7 & Bouillon et al. (2007a) \\
\hline Mtoni $(\mathrm{TZ})^{\mathrm{b}}$ & 26 & 39.3 & -6.9 & 7.3 & Kristensen et al. (2008) \\
\hline Ras Dege Creek (TZ) & 26 & 39.5 & -6.9 & 12.4 & Bouillon et al. (2007c) \\
\hline Matolo/Ndogwe/Kalota/Mto Tana (KE) & 27 & 40.1 & -2.1 & 25.8 & Bouillon et al. (2007b) \\
\hline Kali (IN) ${ }^{\mathrm{b}}$ & 30 & 74.8 & 14.2 & 1.2 & Sarma et al. (2012) \\
\hline Mandovi (IN) ${ }^{\mathrm{b}}$ & 30 & 73.8 & 15.4 & 6.6 & Sarma et al. (2012) \\
\hline Netravathi (IN) ${ }^{\mathrm{b}}$ & 30 & 74.9 & 12.9 & 25.8 & Sarma et al. (2012) \\
\hline Sharavathi (IN) ${ }^{\mathrm{b}}$ & 30 & 74.4 & 14.3 & 3.7 & Sarma et al. (2012) \\
\hline Zuari $(\mathrm{IN})^{\mathrm{b}}$ & 30 & 73.8 & 15.4 & 2.3 & Sarma et al. (2012) \\
\hline Ambalayaar (IN) ${ }^{\mathrm{b}}$ & 31 & 79.5 & 10 & 0.0 & Sarma et al. (2012) \\
\hline Baitarani $(\mathrm{IN})^{\mathrm{b}}$ & 31 & 86.5 & 20.5 & 7.3 & Sarma et al. (2012) \\
\hline Cauvery (IN) ${ }^{b}$ & 31 & 79.8 & 11.4 & 0.8 & Sarma et al. (2012) \\
\hline Gaderu Creek (IN) ${ }^{b}$ & 31 & 82.3 & 16.8 & 20.4 & Borges et al. (2003) \\
\hline Krishna $(\mathrm{IN})^{\mathrm{b}}$ & 31 & 81 & 16 & 2.5 & Sarma et al. (2012) \\
\hline Mooringanga Creek $(\mathrm{IN})^{\mathrm{b}}$ & 31 & 89 & 22 & 8.5 & Borges et al. (2003) \\
\hline Nagavali (IN) ${ }^{\mathrm{b}}$ & 31 & 84 & 18.2 & 0.1 & Sarma et al. (2012) \\
\hline Penna (IN) $)^{\mathrm{b}}$ & 31 & 80 & 14.5 & 1.9 & Sarma et al. (2012) \\
\hline Rushikulya (IN) $^{\mathrm{b}}$ & 31 & 85 & 19.5 & 0.0 & Sarma et al. (2012) \\
\hline Saptamukhi Creek (IN) ${ }^{\mathrm{b}}$ & 31 & 89 & 22 & 20.7 & Borges et al. (2003) \\
\hline Vaigai $(\mathrm{IN})^{\mathrm{b}}$ & 31 & 79.8 & 10 & 0.1 & Sarma et al. (2012) \\
\hline Vamsadhara $(\mathrm{IN})^{\mathrm{b}}$ & 31 & 84.1 & 18.3 & 0.1 & Sarma et al. (2012) \\
\hline $\operatorname{Vellar}(\mathrm{IN})^{\mathrm{b}}$ & 31 & 79 & 10 & 6.2 & Sarma et al. (2012) \\
\hline Khura River estuary $(\mathrm{TH})^{\mathrm{b}}$ & 32 & 98.3 & 9.2 & 35.7 & Miyajima et al. (2009) \\
\hline Trang River estuary $(\mathrm{TH})^{\mathrm{b}}$ & 32 & 99.4 & 7.2 & 30.9 & Miyajima et al. (2009) \\
\hline Nagada Creek (ID) & 37 & 145.8 & -5.2 & 15.9 & Borges et al. (2003) \\
\hline Kiên Vàng creeks $(\mathrm{VN})^{\mathrm{b}}$ & 38 & 105.1 & 8.7 & 34.2 & Koné and Borges (2008) \\
\hline Tam Giang creeks $(\mathrm{VN})^{\mathrm{b}}$ & 38 & 105.2 & 8.8 & 49.3 & Koné and Borges (2008) \\
\hline Elkhorn Slough, Azevedo (US) ${ }^{\mathrm{b}}$ & 2 & -121.8 & 36.8 & $15.2^{\mathrm{a}}$ & Caffrey (2004) \\
\hline Elkhorn Slough, South Marsh (US) ${ }^{b}$ & 2 & -121.8 & 36.8 & $11.2^{\mathrm{a}}$ & Caffrey (2004) \\
\hline South Slough, Stengstacken (US) ${ }^{\mathrm{b}}$ & 2 & -124.3 & 43.3 & $14.5^{\mathrm{a}}$ & Caffrey (2004) \\
\hline South Slough, Winchester (US) ${ }^{\mathrm{b}}$ & 2 & -124.3 & 43.3 & $10.6^{\mathrm{a}}$ & Caffrey (2004) \\
\hline Tijuana River, Oneonta Slough $(\mathrm{MX})^{\mathrm{b}}$ & 2 & -117 & 32.5 & $23.7^{\mathrm{a}}$ & Caffrey (2004) \\
\hline Tijuana River, Tidal Linkage $(\mathrm{MX})^{\mathrm{b}}$ & 2 & -117 & 32.5 & $24.7^{\mathrm{a}}$ & Caffrey (2004) \\
\hline Tomales Bay $(\mathrm{US})^{\mathrm{b}}$ & 2 & -122.9 & 38.1 & $6.3^{\mathrm{a}}$ & Smith and Hollibaugh (1997) \\
\hline$\overline{F \mathrm{CO}_{2}}$, small deltas & & & avg. & 14.7 & \\
\hline
\end{tabular}


Table 5. Continued.

\begin{tabular}{|c|c|c|c|c|c|}
\hline Site & MARCATS & Long. & Lat. & $\begin{array}{r}\overline{F \mathrm{CO}_{2}} \\
\left(\mathrm{~mol} \mathrm{C} \mathrm{m}{ }^{-2} \mathrm{yr}^{-1}\right)\end{array}$ & Reference \\
\hline \multicolumn{6}{|l|}{ Tidal systems } \\
\hline Piauí River estuary (BR) & 6 & -37.5 & -11.5 & 13.0 & Souza et al. (2009) \\
\hline Altamaha Sound (US) ${ }^{\mathrm{b}}$ & 10 & -81.3 & 31.3 & 32.4 & Jiang et al. (2008) \\
\hline Bellamy (US) ${ }^{b}$ & 10 & -70.9 & 43.2 & 3.6 & Hunt et al. (2011) \\
\hline Cocheco (US) ${ }^{\mathrm{b}}$ & 10 & -70.9 & 43.2 & 3.1 & Hunt et al. (2011) \\
\hline Doboy Sound $(\mathrm{US})^{\mathrm{b}}$ & 10 & -81.3 & 31.4 & 13.9 & Jiang et al. (2008) \\
\hline Great Bay (US) ${ }^{b}$ & 10 & -70.9 & 43.1 & 3.6 & Hunt et al. (2011) \\
\hline Little Bay (US) ${ }^{b}$ & 10 & -70.9 & 43.1 & 2.4 & Hunt et al. (2011) \\
\hline Oyster $(\mathrm{US})^{\mathrm{b}}$ & 10 & -70.9 & 43.1 & 4.0 & Hunt et al. (2011) \\
\hline Parker River estuary (US) ${ }^{b}$ & 10 & -70.8 & 42.8 & 1.1 & Raymond and Hopkinson (2003) \\
\hline Sapelo Sound (US) ${ }^{\mathrm{b}}$ & 10 & -81.3 & 31.6 & 13.5 & Jiang et al. (2008) \\
\hline Satilla River (US) ${ }^{\mathrm{b}}$ & 10 & -81.5 & 31 & 42.5 & Cai and Wang (1998) \\
\hline York River $(\mathrm{US})^{\mathrm{b}}$ & 10 & -76.4 & 37.2 & 6.2 & Raymond et al. (2000) \\
\hline Hudson River (tidal) (US) ${ }^{b}$ & 10 & -74 & 40.6 & 13.5 & Raymond et al. (1997) \\
\hline Florida Bay (US) ${ }^{\mathrm{b}}$ & 10 & -80.68 & 24.96 & 1.4 & Dufore (2012) (MSc. Thesis) \\
\hline Elbe $(D E)^{b}$ & 17 & 8.8 & 53.9 & 53.0 & Frankignoulle et al. (1998) \\
\hline Ems $(\mathrm{DE})^{\mathrm{b}}$ & 17 & 6.9 & 53.4 & 67.3 & Frankignoulle et al. (1998) \\
\hline Rhine $(\mathrm{NL})^{\mathrm{b}}$ & 17 & 4.1 & 52 & 39.7 & Frankignoulle et al. (1998) \\
\hline Scheldt $(\mathrm{BE} / \mathrm{NL})^{\mathrm{b}}$ & 17 & 3.5 & 51.4 & 63.0 & Frankignoulle et al. (1998) \\
\hline Thames $(\mathrm{UK})^{\mathrm{b}}$ & 17 & 0.9 & 51.5 & 73.6 & Frankignoulle et al. (1998) \\
\hline Douro $(\mathrm{PT})^{\mathrm{b}}$ & 19 & -8.7 & 41.1 & 76.0 & Frankignoulle et al. (1998) \\
\hline Gironde $(\mathrm{FR})^{\mathrm{b}}$ & 19 & -1.1 & 45.6 & 30.8 & Frankignoulle et al. (1998) \\
\hline Guadalquivir (ES) ${ }^{\mathrm{b}}$ & 19 & -6 & 37.4 & 31.1 & de La Paz et al. (2007) \\
\hline Loire $(\mathrm{FR})^{\mathrm{b}}$ & 19 & -2.2 & 47.2 & 27.1 & Bozec et al. (2012) \\
\hline Sado $(\mathrm{PT})^{\mathrm{b}}$ & 19 & -8.9 & 38.5 & 31.3 & Frankignoulle et al. (1998) \\
\hline Saja-Besaya $(E S)^{b}$ & 19 & -2.7 & 43.4 & 52.2 & Ortega et al. (2005) \\
\hline $\operatorname{Tamar}(\mathrm{UK})^{\mathrm{b}}$ & 19 & -4.2 & 50.4 & 74.8 & Frankignoulle et al. (1998) \\
\hline Betsiboka (MG) & 26 & 46.3 & -15.7 & 3.3 & Ralison et al. (2008) \\
\hline Tana (KE) & 27 & 40.1 & -2.1 & 47.9 & Bouillon et al. (2007b) \\
\hline Bharatakulza $^{\mathrm{b}}$ & 30 & 75.9 & 10.8 & 4.3 & Sarma et al. (2012) \\
\hline Mandovi-Zuari (IN) ${ }^{\mathrm{b}}$ & 30 & 73.5 & 15.3 & 14.2 & Sarma et al. (2011) \\
\hline Narmada (IN) ${ }^{b}$ & 30 & 72.8 & 21.7 & 3.2 & Sarma et al. (2012) \\
\hline Sabarmati (IN) ${ }^{b}$ & 30 & 73 & 21 & 3.7 & Sarma et al. (2012) \\
\hline Sabarmati (IN) ${ }^{b}$ & 30 & 73 & 21 & 5.1 & Sarma et al. (2012) \\
\hline Tapti (IN) ${ }^{\mathrm{b}}$ & 30 & 72.8 & 21.2 & 132.3 & Sarma et al. (2012) \\
\hline Haldia Estuary (IN) ${ }^{\mathrm{b}}$ & 31 & 88 & 22 & 4.5 & Sarma et al. (2012) \\
\hline Hooghly (IN) ${ }^{\mathrm{b}}$ & 31 & 88 & 22 & 5.1 & Mukhopadhyay et al. (2002) \\
\hline Subarnalekha ${ }^{\mathrm{b}}$ & 31 & 88.3 & 21.5 & 0.0 & Sarma et al. (2012) \\
\hline Godavari (IN) ${ }^{\mathrm{b}}$ & 31 & 82.3 & 16.7 & 52.6 & Sarma et al. (2011) \\
\hline Camden Haven (Aus) ${ }^{b}$ & 35 & 152.83 & -31.63 & -5.0 & Maher and Eyre (2012) \\
\hline Hastings River (Aus) ${ }^{\mathrm{b}}$ & 35 & 152.91 & -31.4 & -1.0 & Maher and Eyre (2012) \\
\hline Wallis Lake (Aus) ${ }^{\mathrm{b}}$ & 35 & 152.5 & -32.18 & -5.0 & Maher and Eyre (2012) \\
\hline Mekong $(\mathrm{VN})^{\mathrm{b}}$ & 38 & 106.5 & 10 & 30.8 & Borges (unpublished data) \\
\hline Zhujiang (Pearl River) $(\mathrm{CN})^{\mathrm{b}}$ & 38 & 113.5 & 22.5 & 6.9 & Guo et al. (2009) \\
\hline Changjiang (Yangtze) $(\mathrm{CN})$ & 39 & 120.5 & 31.5 & 24.9 & Zhai et al. (2007) \\
\hline Apex, NY Bight (US) ${ }^{b}$ & 10 & -73.2 & 40.1 & $8.4^{\mathrm{a}}$ & Garside and Malone (1978) \\
\hline Chesapeake Bay, Jug Bay (US) ${ }^{b}$ & 10 & -76.0 & 37.0 & $30.9^{\mathrm{a}}$ & Caffrey (2004) \\
\hline Chesapeake Bay, Patuxent Park (US) ${ }^{b}$ & 10 & -76.0 & 37.0 & $14.0^{\mathrm{a}}$ & Caffrey (2004) \\
\hline Chesapeake Bay, Goodwin Island (US) ${ }^{b}$ & 10 & -76.0 & 37.0 & $2.0^{\mathrm{a}}$ & Caffrey (2004) \\
\hline Chesapeake Bay, Taskinas Creek (US) ${ }^{\mathrm{b}}$ & 10 & -76.0 & 37.0 & $2.4^{\mathrm{a}}$ & Caffrey (2004) \\
\hline Delaware Bay, Blackwater Landing (US) ${ }^{\mathrm{b}}$ & 10 & -75.2 & 39.1 & $17.4^{\mathrm{a}}$ & Caffrey (2004) \\
\hline
\end{tabular}


Table 5. Continued.

\begin{tabular}{|c|c|c|c|c|c|}
\hline Site & MARCATS & Long. & Lat. & $\begin{array}{r}\overline{F \mathrm{CO}_{2}} \\
\left(\mathrm{~mol} \mathrm{C} \mathrm{m}^{-2} \mathrm{yr}^{-1}\right)\end{array}$ & Reference \\
\hline Delaware Bay, Scotton Landing (US) ${ }^{b}$ & 10 & -75.2 & 39.1 & $12.1^{\mathrm{a}}$ & Caffrey (2004) \\
\hline Douro $(\mathrm{PT})^{\mathrm{b}}$ & 19 & -8.7 & 41.1 & $15.1^{\mathrm{a}}$ & Azevedo et al. (2006) \\
\hline Ems-Dollar $(\mathrm{GE})^{\mathrm{b}}$ & 17 & 6.9 & 53.4 & $10.1^{\mathrm{a}}$ & Van Es (1977) \\
\hline Great Bay, Great Bay Buoy (US) ${ }^{b}$ & 10 & -70.9 & 43.1 & $5.4^{\mathrm{a}}$ & Caffrey (2004) \\
\hline Great Bay, Squamscott River (US) ${ }^{b}$ & 10 & -70.9 & 43.1 & $7.3^{\mathrm{a}}$ & Caffrey (2004) \\
\hline Hudson River, Tivoli South (US) ${ }^{b}$ & 10 & -74.0 & 40.7 & $12.1^{\mathrm{a}}$ & Caffrey (2004) \\
\hline Mullica River, Buoy 126 (US) ${ }^{b}$ & 10 & 75.8 & 39.8 & $4.8^{\mathrm{a}}$ & Caffrey (2004) \\
\hline Mullica River, Lower Bank (US) ${ }^{\mathrm{b}}$ & 10 & 75.8 & 39.8 & $14.5^{\mathrm{a}}$ & Caffrey (2004) \\
\hline Narragansett Bay, Potters Cove (US) ${ }^{b}$ & 10 & -71.6 & 41.6 & $12.6^{\mathrm{a}}$ & Caffrey (2004) \\
\hline Narragansett Bay, $\mathrm{T}$-wharf (US) ${ }^{\mathrm{b}}$ & 10 & -71.6 & 41.6 & $11.2^{\mathrm{a}}$ & Caffrey (2004) \\
\hline Newport River estuary (US) ${ }^{b}$ & 10 & -76.7 & 34.8 & $5.7^{\mathrm{a}}$ & Kenney et al. (1988) \\
\hline North Carolina, Masonboro Inlet (US) ${ }^{b}$ & 10 & -77.2 & 34.3 & $15.0^{\mathrm{a}}$ & Caffrey (2004) \\
\hline North Carolina, Zeke's Island (US) ${ }^{\mathrm{b}}$ & 10 & -77.8 & 34.2 & $18.4^{\mathrm{a}}$ & Caffrey (2004) \\
\hline North Inlet-Winyah Bay (US) ${ }^{b}$ & 10 & -79.3 & 33.3 & $8.7^{\mathrm{a}}$ & Caffrey (2004) \\
\hline Oosterschelde (NL) ${ }^{\mathrm{b}}$ & 17 & 3.5 & 51.4 & $5.3^{\mathrm{a}}$ & Scholten et al. (1990) \\
\hline Ria de Vigo $(\mathrm{ES})^{\mathrm{b}}$ & 19 & -8.8 & 42.3 & $3.5^{\mathrm{a}}$ & Prego (1993) \\
\hline Ria Formosa $(\mathrm{PT})^{\mathrm{b}}$ & 19 & -7.9 & 37.0 & $2.5^{\mathrm{a}}$ & Santos et al. (2004) \\
\hline San Francisco Bay, North Bay (US) ${ }^{b}$ & 2 & -122.3 & 37.7 & $14.0^{\mathrm{a}}$ & Jassby et al. (1993) \\
\hline San Francisco Bay, South Bay (US) ${ }^{b}$ & 2 & -122.3 & 37.7 & $5.1^{\mathrm{a}}$ & Jassby et al. (1993) \\
\hline Scheldt Estuary (BE/NL) ${ }^{b}$ & 17 & 3.5 & 51.4 & $10.3^{\mathrm{a}}$ & Gazeau et al. (2005a) \\
\hline Southampton Water $(\mathrm{UK})^{\mathrm{b}}$ & 19 & -1.4 & 50.9 & $9.5^{\mathrm{a}}$ & Collins (1978) \\
\hline Urdaibai $(\mathrm{ES})^{\mathrm{b}}$ & 19 & -2.7 & 43.4 & $-6.3^{\mathrm{a}}$ & Revilla et al. (2002) \\
\hline Waquoit Bay, Central Basin (US) ${ }^{b}$ & 10 & -70.6 & 41.6 & $15.0^{\mathrm{a}}$ & Caffrey (2004) \\
\hline Waquoit Bay, Metoxit Point (US) ${ }^{b}$ & 10 & -70.6 & 41.6 & $12.1^{\mathrm{a}}$ & Caffrey (2004) \\
\hline Wells Head of Tide (US) ${ }^{b}$ & 10 & -70.6 & 43.3 & $21.8^{\mathrm{a}}$ & Caffrey (2004) \\
\hline Wells Inlet (US) ${ }^{\mathrm{b}}$ & 10 & -70.6 & 43.3 & $3.4^{\mathrm{a}}$ & Caffrey (2004) \\
\hline$\overline{\mathrm{FCO}_{2}}$, tidal systems & & & avg. & 18.2 & \\
\hline \multicolumn{6}{|l|}{ Lagoons } \\
\hline Brazos River $(\mathrm{BR})^{\mathrm{b}}$ & 9 & -94.8 & 29.4 & 6.6 & Zeng et al. (2011) \\
\hline Neuse River (US) ${ }^{b}$ & 10 & -76.4 & 35.2 & 4.7 & Crosswell et al. (2012) \\
\hline Aveiro Lagoon (PT) & 19 & -8.7 & 40.7 & 12.4 & $\begin{array}{l}\text { Borges and Frankignoulle } \\
\text { (unpublished data) }\end{array}$ \\
\hline s'Albufera des Grau (ES) & 20 & 4.2 & 40 & -3.0 & Obrador and Pretus (2012) \\
\hline Aby Lagoon $(\mathrm{CI})^{\mathrm{b}}$ & 23 & -3.3 & 4.4 & -3.9 & Koné et al. (2009) \\
\hline Ebrié Lagoon $(\mathrm{CI})^{\mathrm{b}}$ & 23 & -4.3 & 4.5 & 31.1 & Koné et al. (2009) \\
\hline Potou Lagoon $(\mathrm{CI})^{\mathrm{b}}$ & 23 & -3.8 & 4.6 & 40.9 & Koné et al. (2009) \\
\hline Tagba Lagoon $(\mathrm{CI})^{\mathrm{b}}$ & 23 & -5 & 4.4 & 18.4 & Koné et al. (2009) \\
\hline Tendo Lagoon $(\mathrm{CI})^{\mathrm{b}}$ & 23 & -3.2 & 4.3 & 5.1 & Koné et al. (2009) \\
\hline Chalakudi (IN) ${ }^{\mathrm{b}}$ & 30 & 76.3 & 10.2 & 4.7 & Sarma et al. (2012) \\
\hline $\operatorname{Cochin}(\mathrm{IN})^{\mathrm{b}}$ & 30 & 76 & 9.5 & 55.1 & Gupta et al. (2009) \\
\hline Chilka (IN) ${ }^{\mathrm{b}}$ & 31 & 85.5 & 19.1 & 31.2 & Muduli et al. (2012) \\
\hline Ponnayaar (IN) ${ }^{\mathrm{b}}$ & 31 & 79.8 & 11.8 & 35.2 & Sarma et al. (2012) \\
\hline ACE, Big Bay Creek (US) ${ }^{b}$ & 10 & -80.3 & 32.5 & $30.9^{\mathrm{a}}$ & Caffrey (2004) \\
\hline ACE, St. Pierre (US) ${ }^{b}$ & 10 & -80.4 & 32.5 & $17.4^{\mathrm{a}}$ & Caffrey (2004) \\
\hline Apalachicola, Bottom (US) ${ }^{b}$ & 9 & -85.0 & 29.7 & $16.4^{\mathrm{a}}$ & Caffrey (2004) \\
\hline Apalachicola, Surface (US) ${ }^{b}$ & 9 & -85.0 & 29.7 & $12.1^{\mathrm{a}}$ & Caffrey (2004) \\
\hline Bojorquez Lagoon (MX) & 8 & -87 & 21.0 & $-17.6^{\mathrm{a}}$ & Reyes and Merino (1991) \\
\hline $\operatorname{Cochin}(\mathrm{IN})^{\mathrm{b}}$ & 30 & 76.0 & 9.5 & $6.3^{\mathrm{a}}$ & Gupta et al. (2009) \\
\hline Copano Bay (US) ${ }^{\mathrm{b}}$ & 9 & -97.1 & 28.1 & $13.5^{\mathrm{a}}$ & Russell and Montagna (2007) \\
\hline Estero Pargo $(\mathrm{MX})^{\mathrm{b}}$ & 9 & -91.6 & 18.6 & $6.5^{\mathrm{a}}$ & Day Jr. et al. (1988) \\
\hline Four league Bay $(\mathrm{US})^{\mathrm{b}}$ & 9 & -91.2 & 29.3 & $8.8^{\mathrm{a}}$ & Randall and Day Jr. (1987) \\
\hline
\end{tabular}


Table 5. Continued.

\begin{tabular}{|c|c|c|c|c|c|}
\hline Site & MARCATS & Long. & Lat. & $\begin{array}{r}\overline{F \mathrm{CO}_{2}} \\
\left(\mathrm{~mol} \mathrm{C} \mathrm{m}^{-2} \mathrm{yr}^{-1}\right)\end{array}$ & Reference \\
\hline Laguna Madre (US) ${ }^{b}$ & 9 & -97.4 & 26.5 & $5.7^{\mathrm{a}}$ & $\begin{array}{l}\text { Odum and Hoskin (1958), } \\
\text { Odum and Wilson (1962), } \\
\text { Ziegler and Benner (1998) }\end{array}$ \\
\hline Lavaca Bay $(\mathrm{US})^{\mathrm{b}}$ & 9 & -96.6 & 28.7 & $11.2^{\mathrm{a}}$ & Russell and Montagna (2007) \\
\hline Mitla Lagoon (MX) & 3 & -96.4 & 16.9 & $13.1^{\mathrm{a}}$ & Mee (1977) \\
\hline Nueces Bay (US) ${ }^{\mathrm{b}}$ & 9 & -97.4 & 27.3 & $-0.1^{\mathrm{a}}$ & Russell and Montagna (2007) \\
\hline Ochlockonee Bay (US) ${ }^{\mathrm{b}}$ & 9 & -84.4 & 30.0 & $4.5^{\mathrm{a}}$ & Kaul and Froelich (1984) \\
\hline Redfish Bay (US) ${ }^{\mathrm{b}}$ & 9 & -97.1 & 27.9 & $20.2^{\mathrm{a}}$ & Odum and Hoskin (1958) \\
\hline Rookery Bay, Blackwater River (US) ${ }^{\mathrm{b}}$ & 9 & -81.4 & 26.0 & $41.1^{\mathrm{a}}$ & Caffrey (2004) \\
\hline Rookery Bay, Upper Henderson (US) ${ }^{\text {b }}$ & 9 & -81.4 & 26.0 & $33.4^{\mathrm{a}}$ & Caffrey (2004) \\
\hline San Antonio Bay (US) ${ }^{b}$ & 9 & -96.7 & 28.3 & $9.8^{\mathrm{a}}$ & Russell and Montagna (2007) \\
\hline Sapelo Flume Dock (US) ${ }^{\mathrm{b}}$ & 10 & -81.2 & 31.5 & $22.3^{\mathrm{a}}$ & Caffrey (2004) \\
\hline Sapelo Marsh Landing (US) ${ }^{b}$ & 10 & -81.2 & 31.5 & $13.6^{\mathrm{a}}$ & Caffrey (2004) \\
\hline Saquarema Lagoon (BR) & 6 & -42.5 & -22.9 & $3.9^{\mathrm{a}}$ & Carmouze et al. (1991) \\
\hline Terminos Lagoon $(\mathrm{MX})^{\mathrm{b}}$ & 9 & -91.6 & 18.6 & $4.4^{\mathrm{a}}$ & Day Jr. et al. (1988) \\
\hline Venice Lagoon (IT) & 20 & 12.3 & 45.4 & $51.0^{\mathrm{a}}$ & Ciavatta et al. (2008) \\
\hline Weeks Bay, Fish River (US) ${ }^{b}$ & 9 & -87.8 & 30.4 & $2.9^{\mathrm{a}}$ & Caffrey (2004) \\
\hline Weeks Bay, Weeks Bay (US) ${ }^{\mathrm{b}}$ & 9 & -87.8 & 30.4 & $4.8^{\mathrm{a}}$ & Caffrey (2004) \\
\hline$\overline{F \mathrm{CO}_{2}}$, lagoons & & & avg. & 15.1 & \\
\hline \multicolumn{6}{|l|}{ Fjords } \\
\hline Bothnian Bay $(\mathrm{FI})^{\mathrm{b}}$ & 18 & 21 & 63 & 3.1 & Algesten et al. (2004) \\
\hline Godthåbsfjord (GL) & 15 & -51.7 & 64 & -7.95 & Rysgaard et al. (2012) \\
\hline Liminganlahti Bay $(\mathrm{FI})^{\mathrm{b}}$ & 18 & 25.4 & 64.9 & 7.5 & Silvennoinen et al. (2008) \\
\hline Randers Fjord (DK) ${ }^{\mathrm{b}}$ & 18 & 10.3 & 56.6 & 17.5 & Gazeau et al. (2005a) \\
\hline Nordasvannet Fjord (NO) & 17 & 5.3 & 60.3 & $3.8^{\mathrm{a}}$ & Wassmann et al. (1986) \\
\hline Padilla Bay, Bay View (US) & 2 & -122.5 & 48.5 & $5.8^{\mathrm{a}}$ & Caffrey (2004) \\
\hline Randers Fjord (DK) & 18 & 10.3 & 56.6 & $4.9^{\mathrm{a}}$ & Gazeau et al. (2005b) \\
\hline$\overline{F \mathrm{CO}_{2}}$, fjords & & & avg. & 5.0 & \\
\hline
\end{tabular}

In MARCATS for which the number of available local $\mathrm{FCO}_{2}$ per estuarine type is less than two, the average emission rate solely reflects the relative distribution in estuarine types. The regions where fjords dominate, such as in the northern parts of America and Europe (LAB, HUD, CAN, NGR, SGR, Fig. 7b), are those where emission rates per unit surface area are the lowest $\left(<10 \mathrm{~mol} \mathrm{C} \mathrm{m}^{-2} \mathrm{yr}^{-1}\right)$. Northwestern Russia (BKS) and North Pacific (NEP, WEP) estuaries are characterized by a mix of fjords and tidal systems, and their emission rates exceed $10 \mathrm{~mol} \mathrm{C} \mathrm{m}^{-2} \mathrm{yr}^{-1}$. In the rest of the world, the average emission rates are usually comprised between 15 and $18 \mathrm{~mol} \mathrm{C} \mathrm{m}^{-2} \mathrm{yr}^{-1}$.

Global average $\mathrm{FCO}_{2}$ per unit surface area for small deltas, tidal systems, lagoons and fjords is $14.7,18.2,15.1$ and $5.0 \mathrm{~mol} \mathrm{C} \mathrm{m}^{-2} \mathrm{yr}^{-1}$, respectively. The $\mathrm{CO}_{2}$ emissions in the first three estuarine types are not significantly different from each other. However, they may vary markedly at the regional scale of MARCATS, for instance, by a factor of 6 in BEN where small deltas exhibit average emission rates of $5.1 \mathrm{~mol} \mathrm{C} \mathrm{m}^{-2} \mathrm{yr}^{-1}$ compared to $33.2 \mathrm{~mol} \mathrm{C} \mathrm{m}^{-2} \mathrm{yr}^{-1}$ for lagoons. Other MARCATS where this regional difference is significant include IBE and NEA, where $F \mathrm{CO}_{2}$ rates per surface area in tidal systems are two times higher than those of other systems. In SEA, on the other hand, small delta outgassing rate is as high as $41.8 \mathrm{~mol} \mathrm{C} \mathrm{m}^{-2} \mathrm{yr}^{-1}$ compared to $18.9 \mathrm{~mol} \mathrm{C} \mathrm{m}^{-2} \mathrm{yr}^{-1}$ for tidal systems. These differences support a regionalized analysis of estuarine $\mathrm{CO}_{2}$ emissions.

Our calculations yield a global $\mathrm{CO}_{2}$ evasion of $0.15 \mathrm{Pg} \mathrm{C} \mathrm{yr}^{-1}$ for all estuaries. In order of decreasing importance, tidal systems, lagoons, fjords and small deltas contribute $0.063 \mathrm{Pg} \mathrm{C} \mathrm{yr}^{-1}, 0.046 \mathrm{Pg} \mathrm{C} \mathrm{yr}^{-1}, 0.025 \mathrm{Pg} \mathrm{C} \mathrm{yr}^{-1}$ and $0.019 \mathrm{PgC} \mathrm{yr}^{-1}$, respectively. The global evasion estimate corresponds to an averaged emission rate per unit surface area of $13 \mathrm{molC} \mathrm{m}^{-2} \mathrm{yr}^{-1}$, which is higher than the mean rate of $6.9 \mathrm{molC} \mathrm{m}^{-2} \mathrm{yr}^{-1}$ proposed by Maher and Eyre (2012) but lower than previous estimates based on direct $F \mathrm{CO}_{2}$ measurements (e.g. $21 \pm 18 \mathrm{~mol} \mathrm{C} \mathrm{m}^{-2} \mathrm{yr}^{-1}$ for Laruelle et al., 2010), although still falling within the range of uncertainty. The smaller $\mathrm{CO}_{2}$ evasion from fjords calculated here $\left(5.1 \mathrm{~mol} \mathrm{C} \mathrm{m}^{-2} \mathrm{yr}^{-1}\right.$, averaged over 7 values) largely explains most of the difference between our estimate and the one reported from a single measurement 
(17.5 $\left.\mathrm{mol} \mathrm{C} \mathrm{m}^{-2} \mathrm{yr}^{-1}\right)$ in Laruelle et al. (2010). Our analysis reveals that the spatial coverage of field data remains very coarse for accurate $\mathrm{CO}_{2}$ flux estimations at the global scale, but the spatial resolution of the MARCATS units is well adapted to this scarcity and allows a first regionalized analysis.

\section{Conclusions and outlook}

In this study, a three-level segmentation of the land-ocean continuum extending from the watersheds to the shelf break has been proposed. The spatial resolution of our level I segmentation ( 0.5 degrees) is similar to those of most widely used global hydrological and watershed GIS models. It corresponds to the finest resolution currently available for such models. At this resolution, the routing amongst the vast majority of river networks is properly represented, and terrestrial GIS models are able to produce reliable riverine discharge estimates for large- and medium-sized rivers (watersheds $>$ ten terrestrial cells, Beusen et al., 2005; Vörösmarty et al., 2000b). In addition, important terrestrial and coastal global databases cluster information at the same resolution of 0.5-1 degree (e.g. World Ocean Atlas, Da Silva, 1994, Hexacoral), making combination and meta-analysis between data sets relatively easy. Recent coastal analyses (LOICZ, Buddemeier et al., 2008; Crossland et al., 2005) and typologies (Dürr et al., 2011) as well as GIS models such as the GlobalNEWS initiative (Mayorga et al., 2010; Seitzinger et al., 1995) have also been developed at $0.5-1^{\circ}$. However, with the exception of a few areas around the world (e.g. COSCAT 827 along the east coast of the US), the network of biogeochemically relevant observations of the aquatic continuum is not dense enough at this resolution and calls for an analysis at a coarser resolution (Regnier et al., 2013).

Levels II and III are used to construct large regional entities which retain the most important climatic, morphological and hydrological characteristics of continental waters and the coastal ocean. The resulting number of segments (149 COSCATs and 45 MARCATS) can easily be manipulated and compared to existing segmentations such as the large marine ecosystems (Sherman, 1991) or that of Seiter et al. (2005). The segments provide globally consistent estimates of hypsometric profiles, surface areas and volumes that can be used in combination with databases to establish regional and global biogeochemical budgets. In addition, the inter-compatibility between the three levels allows combining databases compiled at different spatial scales. Here, the segmentation is used to establish regionalized estuarine $\mathrm{CO}_{2}$ flux through the air-water interface. As data are progressively building up, the procedure could easily be extended to inland waters and the coastal ocean. The spatially resolved representation of the hydrological cycle from the river network to the coastal ocean allows also for a quantitative treatment of the water flow routing through the different estuarine types. Both freshwater flow and $\mathrm{CO}_{2}$ budgets are performed at the scale of the MARCATS. In the future, our calculation could also address lateral fluxes of terrestrial carbon, nutrients and further elements relevant in Earth system science. The multi-scale segmentation of the aquatic continuum from land to ocean thus provides appropriate support for the optimal use of global biogeochemical databases (Cai, 2011; Chen et al., 2012; Crossland et al., 2005; Gordon et al., 1996; Laruelle et al., 2010; Nixon et al., 1996; Regnier et al., 2013) and will allow the construction of increasingly robust regionalized budgets of relevance to environmental and climate research.

\section{Supplementary material related to this article is available online at: http://www.hydrol-earth-syst-sci.net/ 17/2029/2013/hess-17-2029-2013-supplement.zip.}

Acknowledgements. The research leading to these results has received funding from the European Union's Seventh Framework Program (FP7/2007-2013) under grant agreement no. 283080, project GEOCARBON, by King Abdullah University of Science and Technology (KAUST) Center-in-Development Award to Utrecht University: project No. KUK-C1-017-12; by the government of the Brussels-Capital Region (Brains Back to Brussels award to PR), by the German Science Foundation DFG (DFGproject HA 4472/6-1) and the Cluster of Excellence "CliSAP" (DFG, EXC177), Universität Hamburg. H. H. Dürr received funding from NSERC (Canada Excellence Research Chair in Ecohydrology - Philippe van Cappellen). N. Goossens is funded by a FRIA (FRS-FNRS) grant.

Edited by: G. Di Baldassarre

\section{References}

Abril, G. and Borges, A. V.: Carbon dioxide and methane emissions from estuaries, in: Greenhouse Gases Emissions from Natural Environments and Hydroelectric Reservoirs: Fluxes and Processes, edited by: Tremblay, A., Varfalvy, L., Roehm, C., and Garneau, M., Springer, Berlin, 187-207, 2004.

Al-Barakati, M. A., James, A. E., and Karakas, G. M.: A Circulation Model of the Red Sea, Journal of Faculty of Marine Sciences, 13, 3-17, 2002.

Algesten, G., Wikner, J., Sobek, S., Tranvik, L. J., and Jansson, M.: Seasonal variation of $\mathrm{CO}_{2}$ saturation in the Gulf of Bothnia: indications of marine net heterotrophy, Global Biogeochem. Cy., 18, GB4021, doi:10.1029/2004GB002232, 2004.

Anderson, J. B.: Antarctic Marine Geology, Cambridge: Cambridge University Press, 1999.

Arndt, S., Vanderborght, J.-P., and Regnier, P.: Diatom growth response to physical forcing in a macrotidal estuary: Coupling hydrodynamics, sediment transport, and biogeochemistry, J. Geophys. Res., 112, 1-23, doi:10.1029/2006JC003581, 2007. 
Arndt, S., Regnier, P., and Vanderborght, J.-P.: SeasonallyResolved Nutrient Export Fluxes and Filtering Capacities in a Macrotidal Estuary, J. Marine Syst., 78, 42-58, doi:10.1016/j.jmarsys.2009.02.008, 2009.

Atkinson, L. P., Huthnance, J. M., and Blanco, J. L.: Circulation, mixing and the distribution of remineralized nutrients, in: The Sea, edited by: Robinson, A. R. and Brink, K. H., Vol. 13, Harvard Univ Press, Cambridge, 227-268, 2005.

Atroosh, K. B. and Moustafa, A. T.: An Estimation of the Probability Distribution of Wadi Bana Flow in the Abyan Delta of Yemen, J. Agr. Sci., 4, 80-89, doi:10.5539/jas.v4n6p80, 2012.

Azevedo, I. C., Duarte, P. M., and Bordalo, A. A.: Pelagic metabolism of the Douro estuary (Portugal) - factors controlling primary production, Estuar. Coast. Shelf S., 69, 133-146, 2006.

Beusen, A. H. W., Dekkers, A. L. M., Bouwman, A. F., Ludwig, W., and Harrison, J.: Estimation of global river transport of sediments and associated particulate C, N, and P, Global Biogeochem. Cy., 19, GB4S05, doi:10.1029/2005GB002453, 2005.

Billen, G., Lancelot, C., and Meybeck, M.: N, P and Si retention along the aquatic continuum from land to ocean. Ocean margin processes in global change: 19-44, edited by: Mantoura, R. F. C., Martin, J. M., and Wollast, R., Dahlem Workshop Reports, Wiley, 1991.

Borges, A. V.: Do we have enough pieces of the jigsaw to integrate $\mathrm{CO}_{2}$ fluxes in the coastal ocean?, Estuaries, 28, 3-27, 2005.

Borges, A. V. and Abril, G.: Carbon dioxide and methane dynamics in estuaries, in: Treatise on Estuarine and Coastal Science, Vol. 5, edited by: Wolanski, E. and McLusky, D. S., 119-161, Academic Press, 2012.

Borges, A. V., Djenidi, S., Lacroix, G., Theate, J., Delille, B., and Frankignoulle, M.: Atmospheric $\mathrm{CO}_{2}$ flux from mangrove surrounding waters, Geophys. Res. Lett., 30, 1558, doi:10.1029/2003GL017143, 2003.

Borges, A. V., Delille, B., and Frankignoulle, M.: Budgeting sinks and sources of $\mathrm{CO}_{2}$ in the coastal ocean: diversity of ecosystems counts, Geophys. Res. Lett., 32, L14601, doi:10.1029/2005GL023053, 2005.

Bouillon, S., Dehairs, F., Schiettecatte, L.-S., and Borges, A. V.: Biogeochemistry of the Tana estuary and delta (northern Kenya), Limnol. Oceanogr., 52, 45-59, 2007a.

Bouillon, S., Dehairs, F., Velimirov, B., Abril, G., and Borges, A. V.: Dynamics of organic and inorganic carbon across contiguous mangrove and seagrass systems (Gazi bay, Kenya), J. Geophys. Res.-Biogeo., 112, G02018, doi:10.1029/2006JG000325, 2007b.

Bouillon, S., Middelburg, J. J., Dehairs, F., Borges, A. V., Abril, G., Flindt, M. R., Ulomi, S., and Kristensen, E.: Importance of intertidal sediment processes and porewater exchange on the water column biogeochemistry in a pristine mangrove creek (Ras Dege, Tanzania), Biogeosciences, 4, 311-322, doi:10.5194/bg-4311-2007, 2007c

Bozec, Y., Cariou, T., Macé, E., Morin, P., Thuillier, D., and Vernet, M.: Seasonal dynamics of air-sea $\mathrm{CO}_{2}$ fluxes in the inner and outer Loire estuary (NW Europe), Estuar. Coast. Shelf S., 100, 58-71, doi:10.1016/j.ecss.2011.05.015, 2012.

Brink, K. H., Abrantes, F. F. G., Bernal, P. A., Dugdale, R. C., Estrada, M., Hutchings, L., Jahnke, R. A., Muller, P. J., and Smith, R. L.: Group report: How do coastal upwelling systems operate as integrated physical, chemical, and biological systems and influence the geological record?, in: Upwelling in the Ocean:
Modern Processes and Ancient Records, edited by: Summerhayes, C. P., Emeis, K.-C., Angel, M. V., Smith, R. L., and Zeitzeschel, B., 103-124, 1995.

Buddemeier, R. W., Smith, S. V., Swaney, D. P., Crossland, C. J., and Maxwell, B. A.: Coastal typology: an integrative "neutral" technique for coastal zone characterization and analysis, Estuar. Coast. Shelf S., 77, 197-205, 2008.

Caffrey, J. M.: Factors controlling net ecosystem metabolism in U.S. estuaries, Estuaries, 27, 90-101, 2004.

Cai, W. J.: Estuarine and coastal ocean carbon paradox: $\mathrm{CO}_{2}$ sinks or sites of terrestrial carbon incineration?, Annu. Rev. Marine Sci., 3, 123-145, 2011.

Cai, W.-J. and Wang, Y.: The chemistry, fluxes, and sources of carbon dioxide in the estuarine waters of the Satilla and Altamaha Rivers, Georgia, Limnol. Oceanogr., 43, 657-668, 1998.

Cai, W. J., Dai, M. H., and Wang, Y. C.: Air sea exchange of carbon dioxide in ocean margins: A province based synthesis, Geophys. Res. Lett., 33, L12603, doi:10.1029/2006GL026219, 2006.

Carmouze, J. P., Knoppers, B., and Vasconcelos, P.: Metabolism of a subtropical Brazilian lagoon, Biogeochemistry, 14, 129-148, 1991.

Chen, C. T. A. and Borges, A. V.: Reconciling opposing views on carbon cycling in the coastal ocean: continental shelves as sinks and near-shore ecosystems as sources of atmospheric $\mathrm{CO}_{2}$, Deep-Sea Res. Pt. II, 56, 578-590, 2009.

Chen, C. T. A., Huang, T. H., Fu, Y. H., Bai, Y., and He, X.: Strong sources of $\mathrm{CO} 2$ in upper estuaries become sinks of $\mathrm{CO}_{2}$ in large river plumes, Curr. Opin. Environ. Sustain., 4, 179-185, 2012.

Ciavatta, S., Pastres, R., Badetti, C., Ferrari, G., and Beck, M. B.: Estimation of phytoplanktonic production and system respiration from data collected by a real-time monitoring network in the Lagoon of Venice, Ecol. Model., 212, 28-36, 2008.

Cole, J. J., Prairie, Y. T., Caraco, N. F., McDowell, W. H., Tranvik, L. J., Striegl, R. G., Duarte, C. M., Kortelainen, P., Downing, J. A., Middelburg, J. J., and Melack, J.: Plumbing the global carbon cycle: Integrating inland waters into the terrestrial carbon budget, Ecosystems, 10, 171-184, 2007.

Collins, K. J.: Fluxes of Organic Carbon and Nutrients in Southampton Waters, Ph.D. Dissertation, University of Southampton, 1978.

Crossland, C. J., Kremer, H. H., Lindeboom, H. J., Marshall Crossland, J. I., and LeTissier, M. D. A.: Coastal Fluxes in the Anthropocene, Global Change - The IGBP Series: Berlin, Heidelberg, Springer, 2005.

Crosswell, J. R., Wetz, M. S., Hales, B., and Paerl, H. W. Air-water $\mathrm{CO}_{2}$ fluxes in the microtidal Neuse River Estuary, North Carolina, J. Geophys. Res.-Oceans, 117, C08017, doi:10.1029/2012jc007925, 2012.

DaSilva, A., Young, A. C., and Levitus, S.: Atlas of surface marine data 1994, Vol. 1: Algorithms and procedures., Tech. Rep. 6, US Department of Commerce, NOAA, NESDIS, 1994.

Day Jr., J. W., Madden, C. J., Ley-Lou, F., Wetzel, R. L., and Navarro, A. M.: Aquatic primary productivity in Terminos lagoon region, in: Ecology of Coastal Ecosystems in the Southern Gulf of Mexico: The Terminos Lagoon Region, edited by: Yàñez-Arancibia, A. and Day Jr., J. W., Universidad Nacional Autónoma de Mexico, Mexico City, 221-236, 1988.

de la Paz, M., Gómez-Parra, A., and Forja, J.: Inorganic carbon dynamic and air-water $\mathrm{CO}_{2}$ exchange in the Guadalquivir Estuary, 
J. Marine Syst., 68, 265-277, 2007.

Déry, S. J. and Wood, E. F.: Decreasing river discharge in northern Canada, Geophys. Res. Lett., 32, L10401, doi:10.1029/2005GL022845, 2005.

Droz, L., Rigaut, F., Cochonat, P., and Tofani, R.: Morphology and recent evolution of the Zaire turbidite system (Gulf of Guinea), Bull. Geol. Soc. Am., 108, 253-269, 1996.

DuFore, C. M.: Spatial and Temporal Variations in the Air-Sea Carbon Dioxide Fluxes of Florida Bay, Gratuate School Thesis, University of South Florida, 2012.

Dürr, H. H., Laruelle, G. G., van Kempen, C. M., Slomp, C. P., Meybeck, M., and Middelkoop, H.: Worldwide Typology of Nearshore Coastal Systems: Defining the Estuarine Filter of River Inputs to the Oceans, Estuar. Coast., 34, 441-458, doi:10.1007/s12237-011-9381-y, 2011.

Engle, V. D., Kurtz, J. C., Smith, L. M., Chancy, C., and Bourgeois, P.: A classification of U.S. estuaries based on physical and hydrologic attributes, Environ. Monit. Assess., 129, 397-412, 2007.

Fekete, B. M., Vörösmarty, C. J., and Grabs W.: High-resolution fields of global runoff combining observed river discharge and simulated water balances, Global Biogeochem. Cy., 16, 1042, doi:10.1029/1999GB001254, 2002.

Ferrón, S., Ortega, T., Gómez-Parra, A., and Forja, J. M.: Seasonal study of $\mathrm{CH}_{4}, \mathrm{CO}_{2}$ and $\mathrm{N}_{2} \mathrm{O}$ in a shallow tidal system of the bay of Cádiz (SW Spain), J. Marine Syst., 66, 244-257, 2007.

Frankignoulle, M., Abril, G., Borges, A., Bourge, I., Canon, C., Delille, B., Libert, E., and Théate, J.-M.: Carbon dioxide emission from European estuaries, Science, 282, 434-436, 1998.

Garside, C. and Malone, T. C.: Monthly oxygen and carbon budgets of the New York Bight Apex, Estuar. Coast. Shelf S., 6, 93-104, 1978.

Gattuso, J.-P., Frankignoulle, M., and Wollast, R.: Carbon and carbonate metabolism in coastal aquatic ecosystems, Annu. Rev. Ecol. Syst., 29, 405-433, 1998.

Gazeau, F., Borges, A. V., Barrón, C., Duarte, C. M., Iversen, N., Middelburg, J. J., Delille, B., Pizay, M.-D., Frankignoulle, M., and Gattuso, J.-P.: Net ecosystem metabolism in a micro-tidal estuary (Randers Fjord, Denmark): evaluation of methods, Marine Ecology Progress Series, 301, 23-41, 2005a.

Gazeau, F., Gattuso, J.-P., Middelburg, J. J., Brion, N., Schiettecatte, L.-S., Frankignoulle, M., and Borges, A. V.: Planktonic and whole system metabolism in a nutrient-rich estuary (the Scheldt estuary), Estuaries, 28, 868-883, 2005b.

Gordon, J. D. C., Boudreau, P. R., Mann, K. H., Ong, J. E., Silvert, W. L., Smith, S. V., Wattayakorn, G., Wulff, F., and Yanagi, T.: LOICZ biogeochemical modelling guidelines. LOICZ reports \& studies, 5. Texel: LOICZ, 1996.

Gross, G. M.: Oceanography: A View of the Earth. Englewood Cliffs: Prentice-Hall, Inc., ISBN 0-13-629659-9, 1972.

Gruber, N., Lachkar, Z., Frenzel, H., Marchesiello, P., Munnich, M., McWilliams, J. C., Nagai, T., and Plattner, G.-K.: Mesoscale eddy-induced reduction in eastern boundary upwelling systems, Nat. Geosci., 4, 787-792, 2011.

Guo, X., Dai, M., Zhai, W., Cai, W.-J., and Chen, B.: $\mathrm{CO}_{2}$ flux and seasonal variability in a large subtropical estuarine system, the Pearl River Estuary, China, J. Geophys. Res., 114, G03013, doi:10.1029/2008JG000905, 2009.

Gupta, G. V. M., Thottathil, S. D., Balachandran, K. K., Madhu, N. V., Madheswaran, P., and Nair, S.: $\mathrm{CO}_{2}$ supersaturation and net heterotrophy in a tropical estuary (Cochin, India): influence of anthropogenic effect, Ecosystems, 12, 1145-1157, 2009.

Hartmann, J., Lauerwald, R., Moosdorf, N., Amann, T., and Weiss, A.: GLORICH: GLobal RIver and estuary CHemical database, ASLO, 13-18 February 2011, San Juan, Puerto Rico, 2011.

Hunt, C. W., Salisbury, J. E., Vandemark, D., and McGillis, W.: Contrasting Carbon Dioxide Inputs and Exchange in Three Adjacent New England Estuaries, Estuar. Coasts, 34, 68-77, 2011.

Jacobs, S. S., Helmer, H. H., Doake, C. S. M., Jenkins, A., and Frolich, R. M.: Melting of ice shelves and the mass balance of Antarctica, J. Glaciol., 38, 375-387, 1992.

Jassby, A. D., Cloern, J. E., and Powell, T. P.: Organic carbon sources and sinks in SanFrancisco Bay: variability induced by a river flow, Marine Ecology Progress Series, 93, 39-54, 1993.

Jiang, L.-Q., Cai, W.-J., and Wang, Y. A.: comparative study of carbon dioxide degassing in river- and marine-dominated estuaries, Limnol. Oceanogr., 53, 2603-2615, 2008.

Karl, D. M.: A Sea of Change: Biogeochemical Variability in the North Pacific Subtropical Gyre, Ecosystems, 2, 181-214, 1999.

Kaul, L. W. and Froelich, P. N.: Modeling estuarine nutrient geochemistry in a simple system, Geochim. Cosmochim. Ac., 48, 1417-1733, 1984.

Kenney, B. E., Litaker, W., Duke, C. S., and Ramus, J.: Community oxygen metabolism in a shallow tidal estuary, Estuar. Coast. Shelf S., 27, 33-43, 1988.

Koné, Y. J. M. and Borges, A. V.: Dissolved inorganic carbon dynamics in the waters surrounding forested mangroves of the $\mathrm{Ca}$ Mau Province (Vietnam), Estuar. Coast. Shelf S., 77, 409-421, 2008.

Koné, Y. J. M., Abril, G., Kouadio, K. N., Delille, B., and Borges, A. V.: Seasonal variability of carbon dioxide in the rivers and lagoons of Ivory Coast (West Africa), Estuar. Coasts, 32, 246260, 2009.

Köppen, W.: Das geographisca System der Klimate, in: Handbuch der Klimatologie, edited by: Köppen, W. and Geiger, G., 1. C. Gebr, Borntraeger, 1-44, 1936.

Kristensen, E., Flindt, M. R., Ulomi, S., Borges, A. V., Abril, G., and Bouillon, $\mathrm{S}$.: Emission of $\mathrm{CO}_{2}$ and $\mathrm{CH}_{4}$ to the atmosphere by sediments and open waters in two Tanzanian mangrove forests, Marine Ecology Progress Series, 370, 53-67, 2008.

Laruelle, G. G.: Quantifying nutrient cycling and retention in coastal waters at the global scale, Ph D dissertation, Utrecht University, 2009.

Laruelle, G. G., Roubeix, V., Sferratore, A., Brodherr, N., Ciuffa, D., Conley, D. J., Dürr, H. H., Garnier, J., Lancelot, C., Le Thi Phuong, Q., Meunier, J.-D., Meybeck, M., Michalopoulos, P., Moriceau, B., Ní Longphuirt, S., Loucaides, S., Papush, L., Presti, M., Ragueneau, O., Regnier, P. A. G., Saccone, L., Slomp, C. P., Spiteri, C., and Van Cappellen, P.: The global biogeochemical cycle of silicon: role of the land-ocean transition and response to anthropogenic perturbation, Global Biogeochem. Cy., 23, GB4031, doi:10.1029/2008GB003267, 2009.

Laruelle, G. G., Dürr, H. H., Slomp, C. P., and Borges, A. V.: Evaluation of sinks and sources of $\mathrm{CO}(2)$ in the global coastal ocean using a spatially-explicit typology of estuaries and continental shelves, Geophys. Res. Lett., 37, L15607, doi:10.1029/2010GL043691, 2010.

Levitus, S., Boyer, T. P., Conkright, M. E., O’ Brien, T., Antonov, J., Stephens, C., Stathoplos, L., Johnson, D., and Gelfeld, R.: 
NOAA Atlas NESDIS 18, World Ocean Database 1998: VOLUME 1: INTRODUCTION, US Gov. Printing Office, Wash. DC, 346 pp., 1998.

Liu, K.-K., Atkinson, L., Quinones, R., and Talaue-McManus, L. (Eds.): Carbon and Nutrient Fluxes in Continental Margins, Global Change - The IGBP Series, 3, Springer-Verlag Berlin Heidelberg, 2010.

Lønborg, C. and Álvarez-Salgado, X. A.: Recycling versus export of bioavailable dissolved organic matter in the coastal ocean and efficiency of the continental shelf pump, Global Biogeochem. Cy., 26, GB3018, doi:10.1029/2012GB004353, 2012.

Longhurst, A.: Seasonal cycles of pelagic production and consumption, Prog. Oceanogr., 36, 77-167, 1995.

Longhurst, A.: Ecological geography of the sea. Academic Press, San Diego, 398 pp., 1998.

Macdonald, R. W. and Kuzyk, Z. Z. A.: The Hudson Bay System, J. Marine Syst., 88, 337-488, 2011.

Mackenzie, F. T., Ver, L. M., Sabine, C., Lane, M., and Lerman, A.: C, N, P, S global biogeochemical cycles and modeling of global change, in: Interactions of C, N, P and S Biogeochemical Cycles and Global Change, edited by: Wollast, R., Mackenzie, F. T., and Chou, L., 1-62, Springer-Verlag, 1993.

Mackenzie, F. T., Ver, L. M., and Lerman, A.: Coupled biogeochemical cycles of carbon, nitrogen, phosphorus, and sulfur in the land-ocean-atmosphere system, in: Asian Change in the Context of Global Change, edited by: Galloway, J. N. and Melillo, J. M., Cambridge University Press, Cambridge, 42-100, 1998.

Mackenzie, F. T., Andersson, A., Lerman, A., and Ver, L. M.: Boundary exchanges in the global coastal margin: implications for the organic and inorganic carbon cycles, in: The Sea, 13, Chapter 7, edited by: Robinson, A. R. and Brink, K. H., Harvard University Press, Cambridge, MA, 193-225, 2005.

Mackenzie, F. T., De Carlo, E. H., and Lerman, A.: Coupled C, N, $\mathrm{P}$, and $\mathrm{O}$ biogeochemical cycling at the land-ocean interface. In Treatise on Estuarine and Coastal Science, edited by: Middelburg, J. J. and Laane, R., Ch. 5.10, Elsevier, 2012.

Maher, D. T. and Eyre, B. D.: Carbon budgets for three autotrophic Australian estuaries: Implications for global estimates of the coastal air-water $\mathrm{CO}_{2}$ flux, Global Biogeochem. Cy., 26, GB1032, doi:10.1029/2011GB004075, 2012.

Mann, K. H. and Lazier, J. R. N.: Dynamics of Marine Ecosystems: Biological-Physical Interactions in the Oceans, 3rd Edn., Blackwell Publishing, 2006.

Mantoura, R. E C., Martin, J.-M., and Wollast, R. (Eds.): Ocean margin processes in global change, Wiley, 1991.

Mayorga, E., Seitzinger, S. P., Harrison, J. A., Dumont, E., Beusen, A. H. W., Bouwman, A. F., Fekete, B. M., Kroeze, C., and Van Drecht, G.: Global Nutrient Export from WaterSheds 2 (NEWS 2): Model development and implementation, Environ. Model. Softw., 25, 837-853, doi:10.1016/j.envsoft.2010.01.007, 2010.

McKee, B. A., Aller, R. C., Allison, M. A., Bianchi, T. S., and Kineke, G. C.: Transport and transformation of dissolved and particulate materials on continental margins influenced by major rivers: Benthic boundary layer and seabed processes, Cont. Shelf Res., 24, 899-926, 2004.

Mee, L. D.: The Chemistry and Hydrography of Some Tropical Coastal Lagoons - Pacific Coast of Mexico, Ph.D. Dissertation, University of Liverpool, 125 pp., 1977.
Meybeck, M. and Dürr, H. H.: Cascading Filters of River Material from Headwaters to Regional Seas: The European Example, in: Watersheds, Bays, and Bounded Seas - The Science and Management of Semi-Enclosed Marine Systems, SCOPE Series 70, editede by: Urban Jr., E. R., Sundby, B., Malanotte-Rizzoli, P., and Melillo, J. M., 115-139, Washington, Island Press, 2009.

Meybeck, M., Dürr, H. H., and Vörosmarty, C. J.: Global coastal segmentation and its river catchment contributors: A new look at land-ocean linkage, Global Biogeochem. Cy., 20, GB1S90, doi:10.1029/2005GB002540, 2006.

Meybeck, M., Kummu, M., and Dürr, H. H.: Global hydrobelts and hydroregions: improved reporting scale for water-related issues?, Hydrol. Earth Syst. Sci., 17, 1093-1111, doi:10.5194/hess-171093-2013, 2013.

Miyajima, T., Tsuboi, Y., Tanaka, Y., and Koike, I.: Export of inorganic carbon from two Southeast Asian mangrove forests to adjacent estuaries as estimated by the stable isotope composition of dissolved inorganic carbon, J. Geophys. Res., 114, G01024, doi:10.1029/2008JG000861, 2009.

Muduli, P. R., Kanuri, V. V., Robin, R. S., Charan Kumar, B., Patra, S., Raman, A. V., Nageswarara Rao, G., and Subramanian, B. R.: Spatio-temporal variation of $\mathrm{CO}_{2}$ emission from Chilika Lake, a tropical coastal lagoon, on the east coast of India, Estuar. Coast. Shelf S., 113, 305-313, doi:10.1016/j.ecss.2012.08.020, 2012.

Mukhopadhyay, S. K., Biswas, H., De, T. K., Sen, S., and Jana, T. $\mathrm{K}$.: Seasonal effects on the air-water carbon dioxide exchange in the Hooghly estuary, NE coast of Gulf of Bengal, India, J. Environ. Monit., 4, 549-552, 2002.

Nag, P.: Coastal geomorphic features around Indian Ocean, Indian Journal of Geo-Marine Sciences, 39, 557-561, 2010.

New York Times: Times atlas of the world: Comprehensive edition, 9th Edn., New York: New York Times, 1992.

Nixon, S. W., Ammenman, J. W., Atkinson, L. P., Berounsky, V. M., Billen, G., Boicourt, W. C., Boynton, W. R., Church, T. M., DiToro, D. M., Elmgren, R., Garber, J. H., Giblin, A. E., Jahnke, R. A., Owens, N. J. P., Pilson, M. E. J., and Seitzinger, S. P.: The fate of nitrogen and phosphorus at the land sea margin of the north Atlantic Ocean, Biogeochemistry, 35, 141-180, 1996.

Obrador, B. and Pretus, J.: Budgets of organic and inorganic carbon in a Mediterranean coastal lagoon dominated by submerged vegetation, Hydrobiologia, 699, 35-54, doi:10.1007/s10750-0121152-7, 2012.

Odum, H. T. and Hoskin, C. M.: Comparative studies of the metabolism of Texas Bays. Publications of the Institute of Marine Science, University of Texas, 5, 16-46, 1958.

Odum, H. T. and Wilson, R.: Further studies on the reaeration and metabolism of Texas Bays, Publications of the Institute of Marine Science, University of Texas, 8, 23-55, 1962.

Ortega, T., Ponce, R., Forja, J., and Gómez-Parra, A.: Fluxes of dissolved inorganic carbon in three estuarine systems of the Cantabrian Sea (north of Spain), J. Marine Syst., 53, 125-142, 2005.

OSPAR: The Quality Status Report, available at: http://qsr2010. ospar.org/en/ (last access: 26 May 2013), 2010.

Pearce, A. F.: The Leeuwin Current and the Houtman Abrolhos Islands, Western Australia, in: The Marine Flora and Fauna of the Houtman Abrolhos Islands, Western Australia, Vol. 1, edited by: Wells, F. E., Perth: Western Australian Museum, 11-46, 1997. 
Peel, M. C., Finlayson, B. L., and McMahon, T. A.: Updated world map of the Köppen-Geiger climate classification, Hydrol. Earth Syst. Sci., 11, 1633-1644, doi:10.5194/hess-11-16332007, 2007.

Pfeil, B., Olsen, A., Bakker, D. C. E., Hankin, S., Koyuk, H., Kozyr, A., Malczyk, J., Manke, A., Metzl, N., Sabine, C. L., Akl, J., Alin, S. R., Bellerby, R. G. J., Borges, A., Boutin, J., Brown, P. J., Cai, W.-J., Chavez, F. P., Chen, A., Cosca, C., Fassbender, A. J., Feely, R. A., González-Dávila, M., Goyet, C., HardmanMountford, N., Heinze, C., Hood, M., Hoppema, M., Hunt, C. W., Hydes, D., Ishii, M., Johannessen, T., Jones, S. D., Key, R. M., Körtzinger, A., Landschützer, P., Lauvset, S. K., Lefèvre, N., Lenton, A., Lourantou, A., Merlivat, L., Midorikawa, T., Mintrop, L., Miyazaki, C., Murata, A., Nakadate, A., Nakano, Y., Nakaoka, S., Nojiri, Y., Omar, A. M., Padin, X. A., Park, G.-H., Paterson, K., Perez, F. F., Pierrot, D., Poisson, A., Ríos, A. F., Santana-Casiano, J. M., Salisbury, J., Sarma, V. V. S. S., Schlitzer, R., Schneider, B., Schuster, U., Sieger, R., Skjelvan, I., Steinhoff, T., Suzuki, T., Takahashi, T., Tedesco, K., Telszewski, M., Thomas, H., Tilbrook, B., Tjiputra, J., Vandemark, D., Veness, T., Wanninkhof, R., Watson, A. J., Weiss, R., Wong, C. S., and Yoshikawa-Inoue, H.: A uniform, quality controlled Surface Ocean $\mathrm{CO}_{2}$ Atlas (SOCAT), Earth Syst. Sci. Data Discuss., 5, 735-780, doi:10.5194/essdd-5-735-2012, 2012.

Pinet, P. R.: Invitation to Oceanography. St. Paul, MN: West Publishing Co., 1996, ISBN 0-7637-2136-0, 3rd Edn., 1996.

Pous, S., Carton, X., and Lazure, P.: A Process Study of the Tidal Circulation in the Persian Gulf, Open Journal of Marine Science, 2, 131-140, doi:10.4236/ojms.2012.24016, 2012.

Prego, R.: General aspects of carbon biogeochemistry in the Ria of Vigo, northwestern Spain, Geochim. Cosmochim. Ac., 57, 20412052, 1993.

Rabouille, C., Mackenzie, F. T., and Ver, L. M.: Influence of the human perturbation on carbon, nitrogen, and oxygen biogeochemical cycles in the global coastal ocean, Geochim. Cosmochim. Ac., 65, 3615-3641, 2001.

Ralison, O. H., Borges, A. V., Dehairs, F., Middelburg, J. J., and Bouillon, S.: Carbon biogeochemistry of the Betsiboka Estuary (north-western Madagascar), Org. Geochem., 39, 1649-1658, 2008.

Randall, J. M. and Day Jr., J. W.: Effects of river discharge and vertical circulation on aquatic primary production in a turbid Louisana (USA) estuary, Neth. J. Sea Res., 21, 231-242, 1987.

Raymond, P. A. and Hopkinson, C. S.: Ecosystem modulation of dissolved carbon age in a temperate marsh-dominated estuary, Ecosystems, 6, 694-705, 2003.

Raymond, P. A., Caraco, N. F., and Cole, J. J.: Carbon Dioxide Concentration and Atmospheric Flux in the Hudson River, Estuaries, 20, 381-390, doi:10.2307/1352351, 1997.

Raymond, P. A., Bauer, J. E., and Cole, J. J.: Atmospheric $\mathrm{CO}_{2}$ evasion, dissolved inorganic carbon production, and net heterotrophy in the York River estuary, Limnol. Oceanogr., 45, 17071717, 2000.

Regnier, P. and Steefel, C. I.: A high resolution estimate of the inorganic nitrogen flux from the Scheldt estuary to the coastal North Sea during a nitrogen-limited algal bloom, spring 1995, Geochim. Cosmochim. Ac., 63, 1359-1374, 1999.

Regnier, P., Friedlingstein, P., Ciais, P., Mackenzie, F. T., Gruber, N., Janssens, I., Laruelle, G. G., Lauerwald, R., Luyssaert, S.,
Andersson, A. J., Arndt, S., Arnosti, C., Borges, A. V., Dale, A. W., Gallego-Sala, A., Goddéris, Y., Goossens, N., Hartmann, J., Heinze, C., Ilyina, T., Joos, F., LaRowe, D. E., Leifeld, J., Meysman, F. J. R., Munhoven, G., Raymond, P. A., Spahni, R., Suntharalingam, P., and Thullner, M.: Anthropogenic perturbation of the land to ocean carbon flux, Nat. Geosci., online first, doi:10.1038/NGEO1830, 2013.

Revilla, M., Ansotegui, A., Iriarte, A., Madariaga, I., Orive, E., Sarobe, A., and Trigueros, J. M.: Microplankton metabolism along a trophic gradient in a shallow-temperate estuary, Estuaries, 25, 6-18, 2002.

Reyes, E. and Merino, M.: Diel dissolved oxygen dynamics and eutrophication in a shallow, well-mixed tropical lagoon (Cancun, Mexico), Estuaries, 14, 372-381, 1991.

Russell, M. J. and Montagna, P. A.: Spatial and temporal variability and drivers of net ecosystem metabolism in Western Gulf of Mexico estuaries, Estuar. Coasts, 30, 137-153, 2007.

Rysgaard, S., Mortensen, J., Juul-Pedersen, T., Sørensen, L. L., Lennert, K., Søgaard, D. H., Arendt, K. E., Blicher, M. E., Sejr, M. K., and Bendtsen, J.: High air-sea $\mathrm{CO}_{2}$ uptake rates in nearshore and shelf areas of Southern Greenland: Temporal and spatial variability, Mar. Chem., 128-129, 26-33, doi:10.1016/j.marchem.2011.11.002, 2012.

Santos, R., Silva, J., Alexandre, A., Navarro, N., Barrón, C., and Duarte, C. M.: Ecosystem metabolism and carbon fluxes of a tidally dominated coastal lagoon, Estuaries, 27, 977-985, 2004.

Sarma, V. V. S. S., Kumar, N. A., Prasad, V. R., Venkataramana, V., Appalanaidu, S., Sridevi, B., Kumar, B. S. K., Bharati, M. D., Subbaiah, C. V., Acharyya, T., Rao, G. D., Viswanadham, R., Gawade, L., Manjary, D. T., Kumar, P. P., Rajeev, K., Reddy, N. P. C., Sarma, V. V., Kumar, M. D., Sadhuram, Y., and Murty, T. V. R.: High $\mathrm{CO}_{2}$ emissions from the tropical Godavari estuary (India) associated with monsoon river discharges, Geophys. Res. Lett., 38, L08601, doi:10.1029/2011GL046928, 2011.

Sarma, V. V. S. S., Viswanadham, R., Rao, G. D., Prasad, V. R., Kumar, B. S. K., Naidu, S. A., Kumar, N. A., Rao, D. B., Sridevi, T., Krishna, M. S., Reddy, N. P. C., Sadhuram, Y., and Murty, T. V. R.: Carbon dioxide emissions from Indian monsoonal estuaries, Geophys. Res. Lett., doi:10.1029/2011GL050709, 2012.

Saucier, F. J., Senneville, S., Prinsenberg, S., Roy, F., Smith, G., Gachon, P., Caya, D., and Laprise, R.: Modeling the ice-ocean seasonal cycle in Hudson Bay, Foxe Basin and Hudson Strait, Canada, Clim. Dynam., 23, 303-326, 2004.

Scholten, H., Klepper, O., Nienhuis, P. H., and Knoester, M.: Oosterschelde estuary (SW Netherlands): a self-sustaining ecosystem?, Hydrobiologia, 195, 201-215, 1990.

Schwartz, M. L.: Encyclopedia of coastal science, Dordrecht: Springer, 2005.

Seiter, K., Hensen, C., and Zabel, M.: Benthic carbon mineralization on a global scale, Global Biogeochem. Cy., 19, GB1010, doi:10.1029/2004GB002225, 2005.

Seitzinger, S. P., Harrison, J. A., Dumont, E., Beusen, A. H. W., and Bouwman, F. B. A.: Sources and delivery of carbon, nitrogen, and phosphorus to the coastal zone: An overview of global Nutrient Export from Watersheds (NEWS) models and their application, Global Biogeochem. Cy., 19, GB4S01, doi:10.2029/2005GB002606, 2005.

Sherman, K.: The Large Marine Ecosystem Concept: Research and Management Strategy for Living Marine Resources, Ecol. Appl., 
1, 350-360, 1991.

Sherman, K. and Alexander, M.: Biomass Yields and Geography of Large Marine Ecosystems, Am. Assoc. Adv. Sci., Selected Symp., 111, 1989.

Silvennoinen, H., Liikanen, A., Rintala, J., and Martikainen, P. J.: Greenhouse gas fluxes from the eutrophic Temmesjoki River and its Estuary in the Liminganlahti Bay (the Baltic Sea), Biogeochemistry, 90, 193-208, 2008.

Smith, S. V. and Hollibaugh, J. T.: Annual cycle and interannual variability of ecosystem metabolism in a temperate climate embayment, Ecol. Monogr., 67, 509-533, 1997.

Smith, W. H. F. and Sandwell, D. T.: Global Seafloor Topography from Satellite Altimetry and Ship Depth Soundings, version $9.1 \mathrm{~b}$, available at: http://topex.ucsd.edu/marine_topo/ (last access: 20 December 2007), 1997.

Souza, M. F. L., Gomes, V. R., Freitas, S. S., Andrade, R. C. B., and Knoppers, B.: Net ecosystem metabolism and nonconservative fluxes of organic matter in a tropical mangrove estuary, Piauí River (NE of Brazil), Estuar. Coasts, 32, 111-122, 2009.

Takahashi, T., Sutherland, S. C., Wanninkhof, R., Sweeney, C., Feely, R. A., Chipman, D. W., Hales, B., Friederich, G., Chavez, F., Sabine, C., Watson, A., Bakker, D. C. E., Schuster, U., Metzl, N., Yoshikawa-Inoue, H., Ishii, M., Midorikawa, T., Nojiri, Y., Körtzinger, A., Steinhoff, T., Hoppema, M., Olafsson, J., Arnarson, T. S., Tilbrook, B., Johannessen, T., Olsen, A., Bellerby, R., Wong, C. S., Delille, B., Bates, N. R., and de Baar, H. J. W.: Climatological mean and decadal change in surface ocean $p \mathrm{CO}_{2}$, and net sea-air $\mathrm{CO}_{2}$ flux over the global oceans, Deep-Sea Res. Pt. II, 56, 554-577, 2009.

Thomas, H., Bozec, Y., de Baar, H. J. W., Elkalay, K., Frankignoulle, M., Schiettecatte, L.-S., Kattner, G., and Borges, A. V.: The carbon budget of the North Sea, Biogeosciences, 2, 87-96, doi:10.5194/bg-2-87-2005, 2005.

Tranvik, L. J., Downing, J. A., Cotner, J. B., Loiselle, S. A., Striegl, R. G., Ballatore, T. J., Dillon, P., Finlay, K., Fortino, K., Knoll, L. B., Kortelainen, P. L., Kutser, T., Larsen, S., Laurion, I., Leech, D. M., McCallister, S. L., McKnight, D. M., Melack, J. M., Overholt, E., Porter, J. A., Prairie, Y., Renwick, W. H., Roland, F., Sherman, B. S., Schindler, D. W., Sobek, S., Tremblay, A., Vanni, M. J., Verschoor, A. M., von Wachenfeldt, E., and Weyhenmeyera, G. A.: Lakes and reservoirs as regulators of carbon cycling and climate, Limnol. Oceanogr., 54, 2298-2314, 2009.

US Department of Commerce: National Oceanic and Atmospheric Administration, National Geophysical Data Center, 2minute Gridded Global Relief Data (ETOPO2v2), available at: http://www.ngdc.noaa.gov/mgg/fliers/06mgg01.html (last access: 26 December 2008), 2006.

Van Es, F. B.: A preliminary carbon budget for a part of the Ems estuary: the Dollard, Helgolander Wiss. Meeresunters, 30, 283 294, 1977.

Vanderborght, J. P., Wollast, R., Loijens, M., and Regnier, P.: Application of a transport-reaction model to the estimation of biogas fluxes in the Scheldt estuary, Biogeochemistry, 59, 207-237, 2002.
Vanderborght, J. P., Folmer, I., Aguilera, D. R., Uhrenholdt, T., and Regnier, P.: Reactive-transport modelling of a river-estuarinecoastal zone system: application to the Scheldt estuary, Mar. Chem., 106, 92-110, 2007.

Ver, L. M.: Global kinetic models of the coupled C, N, P, and S biogeochemical cycles: Implications for global environmental change, Ph.D. dissertation, University of Hawaii, 1998.

Vörösmarty, C. J., Fekete, B. M., Meybeck, M., and Lammers, R. B.: The global system of rivers: Its role in organizing continental land mass and defining land-to-ocean linkages, Global Biogeochem. Cy., 14, 599-621, 2000a.

Vörösmarty, C. J., Fekete, B. M., Meybeck, M., and Lammers, R. B.: Geomorphometric attributes of the global system of rivers at 30-minute spatial resolution, J. Hydrol., 237, 17-39, 2000b.

Walsh, J. J.: On the nature of continental shelves, Academic Press, San Diego, New York, Berkeley, Boston, London, Sydney, Tokyo, Toronto, 1988.

Wang, Z. A. and Cai, W.-J.: Carbon dioxide degassing and inorganic carbon export from a marsh-dominated estuary (the Duplin River): a marsh $\mathrm{CO}_{2}$ pump, Limnol. Oceanogr., 42, 341-352, 2004.

Wanninkhof, R., Park, G.-H., Takahashi, T., Sweeney, C., Feely, R., Nojiri, Y., Gruber, N., Doney, S. C., McKinley, G. A., Lenton, A., Le Quéré, C., Heinze, C., Schwinger, J., Graven, H., and Khatiwala, S.: Global ocean carbon uptake: magnitude, variability and trends, Biogeosciences, 10, 1983-2000, doi:10.5194/bg10-1983-2013, 2013.

Wassmann, P., Naas, K. E., and Johannessen, P. J.: Annual supply and loss of particulate organic carbon in Nordasvannet, a eutropic, land-locked fjord in Western Norway, Rapports et Procès Verbaux des Réunions Conseil International pour l'Exploration de la Mer, 186, 423-431, 1986.

Wulff, F., Bonsdorff, E., Gren, I.-M., Johansson, S., and Stigebrandt, A.: Giving advice on cost effective measures for a cleaner Baltic Sea: a challenge to science, Ambio, 30, 254-259, 2001.

Xie, L. and Hsieh, W. W.: Global wind-induced upwelling, Fisheries Oceanography, 4, 52-67, 1975.

Zeng, F.-W., Masiello, C., and Hockaday, W.: Controls on the origin and cycling of riverine dissolved inorganic carbon in the Brazos River, Texas, Biogeochemistry, 104, 275-291, doi:10.1007/s10533-010-9501-y, 2011.

Zhai, W., Dai, M., and Guo, X.: Carbonate system and $\mathrm{CO}_{2}$ degassing fluxes in the inner estuary of Changjiang (Yangtze) River, China, Mar. Chem., 107, 342-356, 2007.

Ziegler, S. and Benner, R.: Ecosystem metabolism in a subtropical, seagrass-dominated lagoon, Marine Ecology Progress Series, 173, 1-12, 1998. 